ANDRZEJ JANECZEK

Instytut Archeologii i Etnologii Polskiej Akademii Nauk

\title{
MIASTA PRYWATNE NA RUSI KORONNEJ DO KOŃCA XV WIEKU
}

Zarys treści: Ruś Czerwona, włączona do Korony w połowie XIV w., poddana została licznym procesom integrujacym i modernizujacym, w tym urbanizacji. Do końca XV w. powstało tu około 117 miast, zorganizowanych według tego samego modelu miejskiego, jaki stosowano na ziemiach polskich. Spośród nich 69 to miasta prywatne, zakładane przede wszystkim w dobrach możnej i bogatszej szlachty. Przeprowadzona klasyfikacja miast, uwzględniająca ocenę zaludnienia, zamożności, skali konsumpcji i siły ekonomicznej ośrodków, wykazała, że były to niemal wyłącznie małe miasta i miasteczka. Dominacja miast małych była ogólną cechą krajobrazu miejskiego Rusi Czerwonej, lecz w grupie miast prywatnych ujawniła się najsilniej.

The content outline: Red Ruthenia, incorporated into the Crown in mid$-14^{\text {th }}$ century, underwent numerous integration and modernisation processes, including urbanisation. The process of urbanisation led to the creation of ca. 117 towns in Ruthenia until the end of the $15^{\text {th }}$ century; they were all organised according to the urban model applied in the Polish territory. Out of these urban centres, 69 were private towns, founded primarily on the estates of magnates and wealthy nobility. The classification of the towns, encompassing the evaluation of their population, wealth, consumption scale and economic power, shows that they were predominantly small-sized towns and localities. The dominance of small towns was characteristic of the entire urban landscape of Red Ruthenia, but it was most visible among private towns.

Słowa kluczowe: Ruś Czerwona, urbanizacja późnośredniowieczna, prawo niemieckie, miasta prywatne, klasyfikacja miast, małe miasta

Keywords: Red Ruthenia, late medieval urbanization, German law, private towns, town classification, small towns

Miasta późnośredniowiecznej Rusi Koronnej to twór nowej kolonizacji, narastajacej od połowy XIV stulecia w ślad za zmianami politycznymi w Europie Środkowo-Wschodniej: upadkiem księstwa halicko- 
-wołyńskiego i aneksją części jego terytorium do Korony polskiej. Powstawały i rozwijały się wyłącznie w postaci miasta prawa niemieckiego, z reguły magdeburskiego, niezależnie od tego, czy ich poprzednikiem był dawny ośrodek grodowo-miejski, osada wiejska czy zgoła pustka. Wszystkie urządzane były od podstaw według tego samego standardu, począwszy od XIII w. z powodzeniem stosowanego w macierzystych dzielnicach Korony. Ustrojowy i organizacyjny typ samorzadowego miasta komunalnego upowszechnił się na ruskich ziemiach Korony w kształcie dosyć jednolitym. Nowe ośrodki zostały założone w drodze lokacji, na podstawie przywileju władcy, udzielajacego immunitetu, nadającego prawo niemieckie i własna jurysdykcję sprawowana przez wójta i ławę, a także przekazującego koncesje gospodarcze, w tym na urządzenie targu i jarmarków. W zgodzie z praktykowanym wzorcem normowała się kategoria ludności miejskiej i wytwarzały warunki do uzyskania miejskiej autonomii i ukształtowania jej instytucji - rady. Niemal zawsze miasta Rusi przechodziły lokację przestrzenną i uzyskiwały regularne rozplanowanie. Ten model miejski znalazł zastosowanie w procesie urbanizacji dzielnicy zarówno przy budowie miast monarszych, jak i prywatnych - całkowitego novum na Rusi. Druga połowa XIV i XV w. to dla nich okres założycielski.

\section{Ruch zakładania miast prywatnych na tle urbanizacji kraju}

Miejski ruch lokacyjny na Rusi Koronnej zaczą się rozwijać już wkrótce po przełomie politycznym. Opis i analiza tego procesu napotyka trudności źródłowe i braki w opracowaniu. Dokładne przedstawienie rozwoju inicjatyw lokacyjnych możliwe jest dopiero dla XVI w. (przede wszystkim dzięki badaniom Ryszarda Szczygła'), natomiast znajomość wcześniejszych faz jest znacznie słabsza i wymaga wielu jeszcze studiów poświęconym poszczególnym przypadkom. Korzystając z dotychczasowego dorobku badań, przede wszystkim miejskich monografii, artykułów problemowych i prac zbiorczo zestawiających dokonania lokacyjne ${ }^{2}$, można pokusić się o ogólne zaprezentowanie ruchu

${ }^{1}$ R. Szczygieł, Lokacje miast $w$ Polsce XVI wieku, Lublin 1989, s. 257-306; por. M. Bogucka, H. Samsonowicz, Dzieje miast $i$ mieszczaństwa $w$ Polsce przedrozbiorowej, Wrocław 1986, s. 118 nn.

${ }^{2} \mathrm{Z}$ uwagi na liczebność literatury przywołane zostały tylko te ostatnie: M. Horn, Miejski ruch osadniczy na Rusi Czerwonej do końca XV wieku, RDSG, t. 35, 1974, s. 49-74; A. Janeczek, Faktorie, powiaty $i$ dwory. Trzy sfery miejskiego ruchu 
urbanizacyjnego na późnośredniowiecznej Rusi Koronnej, czyniąc jednak zastrzeżenie o konieczności dalszej weryfikacji i uściślenia ustaleń szczegółowych.

W momencie początkowym tego burzliwego rozwoju, czyli w połowie XIV w., tylko cztery ośrodki dawnego księstwa halicko-wołyńskiego miały za sobą doświadczenia wcześniejszego funkcjonowania organizacji miejskiej typu okcydentalnego (gminy miejskie rządzące się w pierwszej połowie XIV w. prawem niemieckim w Przemyślu i Lwowie, samorządowa gmina we Włodzimierzu z tego samego czasu, lokowany w 1339 r. Sanok). Około 1400 r. na ruskich ziemiach Korony (przemyska, sanocka, lwowska, halicka i chełmska) oraz w lennym księstwie bełskim funkcjonowały nie mniej niż 32 miasta. W 1500 r. na tym obszarze istniało łącznie już około 117 miast. Wskaźniki zagęszczenia sieci, niższe w porównaniu z Małopolską jeszcze około 1500 r., za sprawą kolejnych lokacji wyrównały się w ciągu XVI w. ${ }^{3}$

Zestawiony w porządku chronologicznym ciagg przedsięwzięć lokacyjnych nie jest wolny od niejasności i wątpliwości. Wywołuje je przede wszystkim nieznajomość okoliczności przeprowadzenia sporej liczby lokacji, w tym jej daty i sprawców. Brak zachowanych dokumentów założycielskich czy innych źródeł oświetlających początkowe dzieje miasta wymuszał konieczność względnego wyznaczenia daty lokacji jako terminus ante quem $\mathrm{w}$ stosunku do różnych informacji pośrednich, poświadczających miejski charakter ośrodka. Nawet jednak w tych szczęśliwych przypadkach, gdy dysponujemy przywilejem lokacyjnym lub dokumentem właściciela, ewentualnie kontraktem wójtowskim, uzyskujemy jedynie fragment wiedzy o przebiegu procesu lokacyjnego, źródła te odzwierciedlają bowiem różne stadia budowy miasta, częstokroć rozciagnięte w czasie. Powołanie wójtostwa, lokacja prawna i lokacja przestrzenna nie musiały następować w szybkim czy równym

lokacyjnego na Rusi Czerwonej (XIII-XV wiek), w: Procesy lokacyjne miast w Europie Środkowo-Wschodniej, red. C. Buśko, M. Goliński, B. Krukiewicz, Wrocław 2006 (Acta Universitatis Wratislaviensis, 2985), s. 421-445 (część zawartych w tej pracy ustaleń została wykorzystana w niniejszym artykule); por. starsze studia: P. Dąbkowski, Podziat administracyjny województwa ruskiego i betzkiego w XV wieku, Lwów 1939; Я.Р. Кісь, Виникнення і розташування міст на територӥі руського $i$ белзького воєводств від XIV до середини XVI cm., „Архіви України” 1968, nr 1, s. 35-41.

${ }^{3}$ R. Szczygieł, dz. cyt., s. 29, 101; zob. też J. Wyrozumski, Rozwój sieci miejskiej $w$ Małopolsce $w$ średniowieczu $i$ u progu czasów nowożytnych, KHKM, t. 28, 1980, $\mathrm{nr}$ 3, s. 363-372; F. Kiryk, Lokacje miejskie nieudane, translacje miast i miasta zanikte $w$ Małopolsce do połowy XVII stulecia, KHKM, t. 28, 1980, nr 3, s. 373-384; M. Horn, Sieć miejska na Rusi Czerwonej w latach 1340-1648, KHKM, t. 28, 1980, nr 3, s. 431-433; M. Bogucka, H. Samsonowicz, dz. cyt., s. 120-121. 
rytmie po sobie; zwłaszcza ta ostatnia nie jest zazwyczaj poświadczona źródłowo, a jedynym potwierdzeniem jej przeprowadzenia jest wówczas plan miasta.

Innego rodzaju niepewność rodzą częste wahania w sprawie wykonywania władztwa: publicznego (terytorialnego) czy dominialnego (gruntowego). Ustalenie stanu własnościowego jest nierzadko zadaniem niełatwym. I nie chodzi wyłącznie o zmiany w stanie posiadania, nie zawsze dobrze czytelne wobec braków źródłowych, wtedy tajemnicze i trudno wytłumaczalne (Rohatyn), czy o przypadki powikłań majątkowych (Tyczyn) i niejasno rysującej się współwłasności królewsko-prywatnej (Buszcze), ale też o podstawową wątpliwość, jak traktować miasta domeny znajdujące się $\mathrm{w}$ tzw. obiegu zastawnym - czy należa one do kategorii miast królewskich, czy też prywatnych. Granica jest nieostra i była rozmyta już w swej epoce. Na przykład Leżajsk, formalnie należący do domeny, przez kilka pokoleń znajdował się w rękach Tarnowskich-Jarosławskich jako zastaw, ale uważany był za substancję majątkową rodu i stanowił obiekt działów rodzinnych dóbr. Jan Koniecpolski, starosta ratneński, ujął tę dwoistość własności-posiadania (dzierżenia) w zgrabnej, ale nierozstrzygającej kwestii formule „oppidum Rathno regale et hactenus nostrum”. Wahania zostały przesądzone na rzecz kryterium prawnego; miasta zastawiane zostały potraktowane jako królewskie, natomiast te, które były przez króla sprzedawane $\mathrm{w}$ ręce prywatne $\mathrm{z}$ prawem odkupu, zaliczono do prywatnych, mimo że formalnie były one nadal uważane za składniki starostw. Nie wyjaśnia to wszystkich wątpliwości, ponieważ nierzadko tytuł dysponowania majętnościa pozostaje nieznany. Do tego status własnościowy z czasu lokacji trzeba ustalać niezależnie od statusu około 1500 r., kiedy to można skonfrontować ze sobą efekty urbanizacji domeny i dóbr prywatnych, zdarzające się bowiem przepływy między typami własności czyniły tę strukturę do pewnego stopnia płynna. Zależnie od tego, który moment zostaje wzięty pod uwagę, zmieniaja się ogólne kalkulacje liczby miast w poszczególnych grupach. Miast skutecznie lokowanych przez króla było 55, przez prywatnych właścicieli (szlachtę i Kościół katolicki) - 62. Inny wynik daje podsumowanie na koniec badanego okresu. Około 1500 r. 48 miast należało do króla, 69 do prywatnych właścicieli. W całym natomiast okresie, od aneksji

${ }^{4}$ W. Zawitkowska, Nieznany dokument Jana Koniecpolskiego z 29 III 1449 r. (Przyczynek do dziejów Ratna i starostwa ratneńskiego w połowie $X V w$.), w: In tempore belli et pacis. Ludzie, miejsca, przedmioty. Ksiegga pamiatkowa dedykowana prof. dr. hab. Janowi Szymczakowi w 65-lecie urodzin i 40-lecie pracy naukowo-dydaktycznej, red. T. Grabarczyk, A. Kowalska-Pietrzak, T. Nowak, Warszawa 2011, s. 693-700. 
Rusi do 1500 r., 74 miasta znajdowały się w rękach prywatnych, stale lub przejściowo.

Analiza przebiegu ruchu lokacyjnego nasuwa kilka wniosków. Jasno ujawnia się ogólna tendencja do utrzymywania kolejności przekształceń lokacyjnych: od ośrodków największych do coraz mniejszych. Stare ośrodki księstwa halicko-wołyńskiego, lokowane najpierw, po reformie zachowywały zwykle pozycję większych czy średnich miast, a późno obdarzane prawem miejskim osady, te, których rola czy nawet istnienie w czasach ruskich sa niewiadome, bądź te osadzane na surowym korzeniu, na ogół mieściły się w grupie małych miast i miasteczek. Ta prawidłowość przestała obowiązywać później, w XVI i XVII w., gdy Tarnopol, Zamość i Stanisławów, wszystkie bez przeszłości, lokowane od podstaw, zajęły miejsce $\mathrm{w}$ grupie największych miast dzielnicy i stały się ośrodkami o randze regionalnej.

Widoczna jest ponadto nierównomierność udziału różnych typów własności w przedsięwzięciach lokacyjnych. Zwraca uwagę niewielkie zaangażowanie Kościoła katolickiego, wyrażające się zaledwie ośmioma próbami utworzenia własnego miasta przed XVI w., w tym jedna nieudana. Znikomy zakres urbanizacyjnej działalności Kościoła nie zaskakuje, odpowiada bowiem strukturze własności ziemskiej. Ubóstwo Kościoła katolickiego na Rusi, dopiero z czasem rozszerzającego swoje uposażenie, sprawiło, że nie odegrał on tu takiej roli jak na ziemiach polskich, zwłaszcza we wczesnym etapie urbanizacji. Majątkowa słabość Kościoła pozostawiła wolne pole panującemu, królom polskim i książętom mazowieckim, a także umacniającej się dzięki nadaniom własności możnowładczej i szlacheckiej. Początkowa przewaga inicjatyw monarszych zaczęła się stopniowo zmniejszać. Do 1400 r. przeprowadzono 23 lokacje królewskie i książęce, a 9 prywatnych. W ciagu następnego półwiecza proporcje już się wyrównały: 25 lokacji było dziełem władcy, 23 szlachty i 4 Kościoła. W drugiej połowie XV w. lokacje prywatne (23 szlacheckich, 3 kościelne) zdominowały liczbowo inicjatywy królewskie (7). Mocny trend wzrostowy lokacji szlacheckich utrzymywał się niezmiennie także później, w XVI w., podczas gdy rozmach królewskich akcji lokacyjnych wyraźnie opadł po 1450 r. i to na trwale; już nie uaktywniły się one $\mathrm{w}$ przyszłości $\mathrm{w}$ pierwotnym natężeniu (zob. wykres 1).

Pierwszeństwo lokacyjnych inicjatyw władcy jest zrozumiałe ze względu na zasadę regale miejskiego, szczególnie rygorystycznie praktykowanego w księstwie bełskim, pozostajacym do 1462 r. pod panowaniem mazowieckich Piastów. W czasach lenna mazowieckiego nie doszło w księstwie do żadnej lokacji prywatnej. Wszystkie miasta 
w tym okresie to dzieło urbanizacyjnej działalności Siemowita IV. Znamienne, że pierwsza lokacja szlachecka w tej ziemi (Uhnów) pojawiła się pięć miesięcy po likwidacji mazowieckiego władztwa ${ }^{5}$. Pomimo zaniechania, wraz inkorporacja do Korony, polityki miejskiego monopolu w Bełskiem kolejna lokacja szlachecka doszła tu do skutku dopiero w 1503 r. Zdaje się to wskazywać, że na tę specyficzną cechę urbanizacji ziemi bełskiej (od 1462 r. województwa) złożyła się nie tylko polityka mazowieckich Piastów, lecz także brak gotowości miejscowych środowisk szlacheckich, aby przystapić do własnej inwestycji miejskiej.

Wykres 1. Liczba udanych lokacji miejskich na Rusi Koronnej w latach 1350-15506

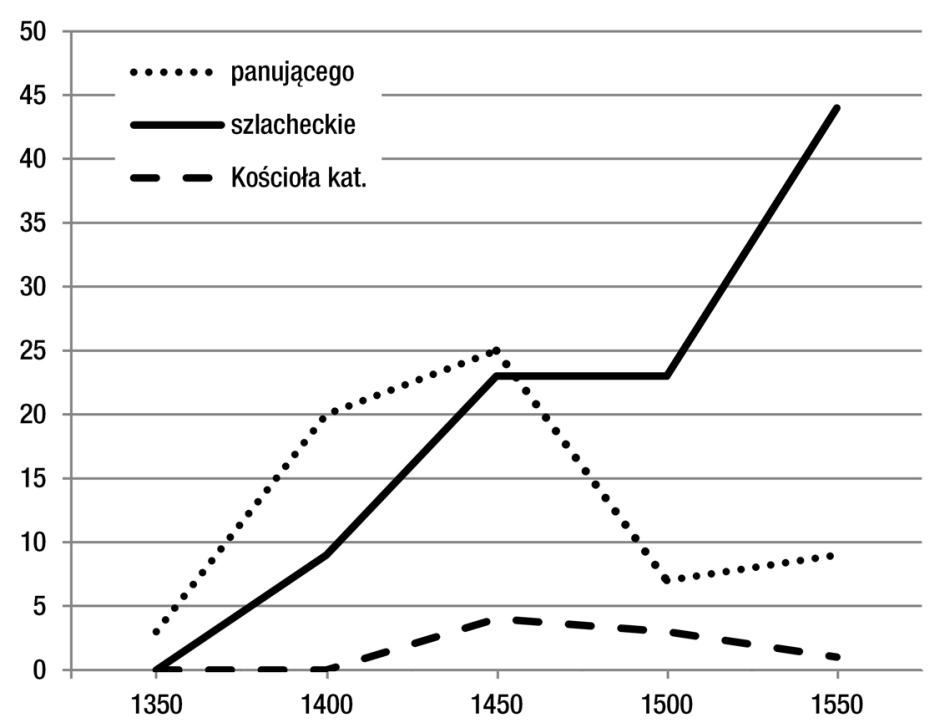

W innych ziemiach Rusi należących do Korony początkowy prymat władcy $\mathrm{w}$ procesie urbanizacji można tłumaczyć wcześniejszym zorganizowaniem majątków królewskich w zdobytej prowincji. Liczebna przewaga miast prywatnych wytworzyła się później, w następstwie formowania i konsolidowania dóbr szlacheckich pochodzących w głównej mierze z nadań udzielanych na wielką skalę między połową XIV i połową XV w. Można sądzić, że powszechniejsza potrzeba miasta prywatnego pojawiła się po apogeum najbardziej intensywnego rozdawnictwa dóbr,

${ }^{5}$ A. Janeczek, Osadnictwo pogranicza polsko-ruskiego. Województwo betskie od schytku XIV do poczatku XVII w., Wrocław 1991, s. $239 \mathrm{nn}$.

${ }^{6}$ Podstawę dla sporządzenia wykresu 1 i map 1-6 stanowią badania własne oraz literatura przedstawiona w przyp. 2. 
po okrzepnięciu majątków szlacheckich i możnowładczych, po wykrystalizowaniu centrów tych nowych organizmów własnościowych - kandydatów do przeprowadzenia lokacji. Prywatne inicjatywy lokacyjne wzmogły się w czasie następującym po restytucji polskiego władztwa nad Rusią w 1387 r., w dobie jagiellońskiej, a zaczęły nasilać zwłaszcza od drugiego-trzeciego dziesięciolecia XV w.; na każdą dekadę do końca stulecia przypadało wówczas przeciętnie sześć lokacji szlacheckich i kościelnych. Natomiast te wcześniejsze, mniej liczne, z reguły realizowane były w kompleksach dóbr, które droga nadania w całości przechodziły w ręce prywatne jako gotowe, zintegrowane majętności z ustalonym w swej funkcji centralnej ośrodkiem i podległym zapleczem.

Najstarsze lokacje - bez względu na charakter własności - wykazuja regularna w sporym stopniu zależność od sieci grodów terytorialnych - późniejszych ośrodków powiatowych. Sieć powiatów zakładana była na podwalinach systemu grodowego Rusi książęcej, struktury trwałej, stabilnej i mocno wrośniętej w krajobraz osadniczy ${ }^{7}$ Żywotność tej struktury przejawiła się w pierwszej fazie budowy organizacji terytorialnej nowych instytucji zaprowadzanych po aneksji kraju: administracji, sądownictwa, sieci parafialnej Kościoła katolickiego. Jej nadal czynne oddziaływanie widoczne jest również w zaczątkowej sieci miast lokacyjnych. Tworzyły ją stolice starych udziałów kniaziowskich oraz ośrodki wołości-powiatów należące do domeny monarszej, ale także te, które zostały nadane wraz z podległym okręgiem i częścią uprawnień terytorialnych możnym rodom szlacheckim i bojarskim.

Powiaty nadawane były od początku akcji rozdawniczej na Rusi. Pierwsze nadania udzielone były przez Kazimierza Wielkiego: Jan Pakosławicz ze Stróżysk otrzymał okręg Rzeszowa, Otto z Pilicy okręg Łańcuta i przypuszczalnie Tyczyna ${ }^{8}$. Dzięki donacjom Władysława Opolczyka Jasiek Kmita otrzymał okręg Buska, Jasiek Kustra okręg Krzeszowa (zapewne), Michał Awdaniec okręg Buczacza (prawdopodobnie w kilku etapach) ${ }^{9}$. Ludwik Węgierski nadał Dymitrowi Korczakowi

${ }^{7}$ A. Janeczek, System grodowo-terytorialny Rusi halickiej w źródtach późnego średniowiecza, w: Lokalne ośrodki władzy państwowej $w$ XI-XII wieku w Europie Środkowo-Wschodniej, Wrocław 1993 (Spotkania Bytomskie, 1), s. 143-157.

${ }^{8}$ KDP, t. 1, wyd. J. Bartoszewicz, Varsaviae 1847, nr 119; B. Wyrozumska, Otto $z$ Pilicy, w: PSB, t. 24, Wrocław 1979, s. 634-635.

${ }_{9}$ Archiwum ksiażat Sanguszków w Stawucie, t. 5, wyd. B. Gorczak, Lwów 1897, $\mathrm{nr} 5$; Katalog dokumentów pergaminowych ze zbiorów Tomasza Niewodniczańskiego $w$ Bitburgu, oprac. J. Tomaszewicz, M. Zdanek, red. W. Bukowski, Kraków 2004, nr 11; ZDM, t. 1-8, wyd. I. Sułkowska-Kuraś, S. Kuraś, Wrocław 1962-1975, nr 1036, 1087, 2012. 
okręgi Goraja i Szczebrzeszyna ${ }^{10}$. Władysław Jagiełło nadał okręg Sambora oraz pięć okręgów na zachodnim Podolu Spytkowi z Melsztyna, okręg Jarosławia Janowi z Tarnowa, zwrócił okręg Tyczyna Janowi Pileckiemu ${ }^{11}$. Władysław Warneńczyk przekazał prawem dziedzicznym okręg Oleska Janowi z Sienna, wcześniej oddany temuż w zastaw przez Jagiełłę ${ }^{12}$.

Przejęcie całych okręgów-powiatów wraz z szerokimi uprawnieniami zwierzchnimi, administracyjnymi, gospodarczymi i sądowniczymi, obejmującymi nawet miejscową szlachtę, otwierało drogę do budowania prywatnych władztw terytorialnych, wręcz ku temu w naturalny sposób wiodło, choć nie zawsze te szanse zostały w pełni wykorzystane. Wielkość i zwartość nadanego latyfundium, ustalona więź podległości wobec naczelnego ośrodka - grodu, równoczesna cesja części praw monarszych, czasem nawet posunięta do przekazania pełnej władzy terytorialnej (dominium directum, plenum ius ducale) bądź udzielenia niektórych regaliów, w tym miejskiego czy zamkowego, dawały możliwości szybkiego utworzenia na wpół udzielnych księstw - seniorii ${ }^{13}$. Lokacja miejska w ośrodku włości doskonale służyła planom tworzenia i umacniania władztwa terytorialnego. Poza korzyściami organizacyjnymi, fiskalnymi, prestiżowymi i propagandowymi, a także walorami obronnymi, przyczyniała się do skonsolidowania władztwa za sprawą tych wszystkich więzi, które łączyły miasto z jego zapleczem.

${ }^{10}$ KDMłp., t. 3, wyd. F. Piekosiński, Kraków 1887, nr 893; ZDM, nr 1136, 1523, 1554; por. K. Myśliński, Dzieje kariery politycznej w średniowiecznej Polsce. Dymitr $z$ Goraja 1340-1400, Lublin 1981, s. $145 \mathrm{nn}$.

${ }_{11}$ AGZ, t. 6, wyd. O. Pietruski, K. Liske, Lwów 1876, nr 3; Codex epistolaris Vitoldi magni ducis Lithuaniae, t. 1, wyd. A. Prochaska, Cracoviae 1882, nr 115; KDMłp., t. 4, Kraków 1905, nr 991; ZDM, nr 1896.

12 ZDM, nr 2308; Z. Spieralski, Jan z Sienna i Oleska, w: PSB, t. 10, Wrocław 1962-1964, s. 475-476; J. Szyszka, Dobra królewskie w ziemi lwowskiej od połowy XIV do poczatku XVI wieku, Kraków 2016 [w druku].

${ }_{13}$ A. Prochaska, Lenna $i$ maństwa na Rusi i Podolu, Kraków 1901 (nadbitka z RAU hf, t. 42), s. 14 nn.; tenże, O wyzwoleniu z maństwa na Rusi, KH, t. 21, 1907, s. 654-657; S. Gawęda, Możnowładztwo małopolskie w XIV i w pierwszej połowie XV wieku, Kraków 1966, s. 52 nn., 60 nn.; W. Dworzaczek, Leliwici Tarnowscy. Z dziejów możnowładztwa małopolskiego, wiek XIV-XV, Warszawa 1971, s. 99 nn., 107 nn., 123 nn., 287 nn.; M. Stankowa, Dawny powiat szczebrzeski XIV-XVIII w., Warszawa 1975, s. 22 nn.; J. Kus, Manowie jarostawscy. $Z$ zagadnień stosunków lennych na Rusi Czerwonej (XIV-XVI w.), „Przemyskie Zapiski Historyczne” 3, 1985, s. 19-35; F. Sikora, Krag rodzinny i dworski Dymitra $z$ Goraja i jego rola na Rusi, w: Genealogia - kregi zawodowe i grupy interesu w Polsce średniowiecznej na tle porównawczym, red. J. Wroniszewski, Toruń 1989, s. 78 nn.; J. Kurtyka, Enfeoffment and Clientship in the Late Mediaeval Kingdom of Poland. The Case of Red Ruthenia (Rus'), „Quaestiones Medii Aevi Novae" 5, 2000, s. 267-278. 
Atuty posiadania własnego ośrodka miejskiego i ułatwione sytuacją warunki jego powołania mobilizowały nowych właścicieli wołości-powiatów do bezzwłocznego przeprowadzania lokacji. Te natychmiastowe starania okazały się skuteczne w większości przypadków; w niektórych z nich przekształcenia lokacyjne poprzedzały nawet wydanie dokumentu donacyjnego. Udały się lokacje Rzeszowa Półkoziców ze Stróżysk (tu proces lokacyjny być może został zainicjowany nieco wcześniej przed donacja z 1354 r. $)^{14}$, Tyczyna i Łańcuta Jana z Pilicy ${ }^{15}$, Jarosławia i Przeworska oraz Sambora Leliwitów z Tarnowa i Melsztyna ${ }^{16}$, Buczacza Awdańców ${ }^{17}$, Szczebrzeszyna Korczaków z Goraja ${ }^{18}$, Oleska Sienieńskich ${ }^{19}$. Inaczej potoczyły się losy Buska i Krzeszowa, gdzie prywatne władztwo terytorialne szybko się rozpadło; ten pierwszy został lokowany w 1411 r. (lub może wcześniej) przez Siemowita IV, ten drugi dopiero w XVII w.

Właściciele tych nowo nadanych powiatów postępowali drogą sprawdzoną i wielokrotnie praktykowana. Dalekim prawzorcem były metody kompleksowego zagospodarowywania włości stosowane w czasach kolonizacji niemieckiej: osadzanie nowych wsi, powoływanie centralnych ośrodków gospodarczych i administracyjnych, w tym zwłaszcza organizacja targów - miejsc lokalnej wymiany handlowej, wznoszenie zamku - warowni, rezydencji i symbolu władzy. Wzorce bliższe dawała prowadzona przez Kazimierza Wielkiego reorganizacja domeny poprzez budowę władztw terytorialnych czy na zbliżonych zasadach tworzone włości majątkowe małopolskich możnych, np. nieco wcześniejszy

${ }_{14}$ J. Kurtyka, Osadnictwo średniowieczne. Poczatki osady i miasta, w: Dzieje Rzeszowa, t. 1, red. F. Kiryk, Rzeszów 1994, s. 97-166.

${ }^{15}$ Król Kazimierz powierzył w 1368 r. Bertoldowi Tycznerowi lokację miasta Tyczyna; KDMłp., t. 4, nr 1084. Z 1369 r. pochodzi informacja, że miasto Łańcut używa prawa niemieckiego; zob. ZDM, nr 1000.

16 Wójt jarosławski znany z 1370 r.; zob. AGZ, t. 7, Lwów 1878, nr 8. Przywilej lokacyjny Jarosławia i translacja miasta, dokument Władysława Opolczyka z 1375 r.; zob. AGZ, t. 7, nr 12; por. J. Kus, W sprawie lokacji Jarosławia, „Studia Historyczne” 25, 1982, z. 2, s. 325-331. Przywilej lokacyjny Jagiełły dla Przeworska z 1393 r.; zob. ZDM, nr 1590. Nadanie wójtostwa w Samborze z zadaniem przeprowadzenia lokacji miasta, wystawione przez Spytka z Melsztyna w 1390 r.; zob. AGZ, t. 6, nr 2.

17 Okoliczności lokacji nieznane, Buczacz został nazwany miastem w dokumencie fundacji kościoła parafialnego wydanym przez Michała Awdańca w 1379 r.; zob. AGZ, t. 5, Lwów 1875, nr 15.

${ }_{18}$ Przywilej lokacyjny nieznany, być może udzielony przed 1388 r.; por. R. Szczygieł, Proces lokacji na prawie niemieckim miasta Szczebrzeszyna, „Annales Academiae Paedagogicae Cracoviensis", Studia Historica 3, 2004, s. 195-202 (tu zestawione starsze poglądy).

${ }^{19}$ Przed 1441 r.; zob. ZDM, nr 2308. 
program zaprowadzony we włości tarnowskiej przez komesa Spycimira, dziada panów na Jarosławiu i Samborze ${ }^{20}$. Była między tymi programami znacząca różnica: kolonizacja późnośredniowieczna wykorzystywała pełny model miejski, w różnych modyfikacjach, a nie model wsi targowej czy ośrodka miejskiego pozbawionego ustroju samorządowego i blokowego układu przestrzennego.

Ruch przekształcania ośrodków grodowych w miasta prawa niemieckiego wyczerpał swoje cele już za panowania Władysława Jagiełły. Ostatnie, spóźnione lokacje w starych centrach grodowych to królewskie Ratno dzierżone z przerwami przez kniazia Sanguszkę i przekazane wraz ze swoim okręgiem jako starostwo Janowi Koniecpolskiemu oraz Olesko nadane Janowi Sienieńskiemu wraz z podległym powiatem. Objęcie ich akcją lokacyjną dopiero około 1440 r. wynikło z późnego włączenia tych pogranicznych okręgów do Rusi Koronnej, po śmierci Witolda, wojnie ze Świdrygiełłą i zawarciu unii grodzieńskiej (1432) ${ }^{21}$.

Dzięki ulokowanym w centrach powiatowych inwestycjom miejskim Kazimierza Wielkiego, Władysława Opolczyka, Władysława Jagiełły i Siemowita IV oraz możnowładczych rodów władających nadanymi im okręgami całe terytorium Rusi Koronnej pokryło się w ciagu 80-90 lat siecią miejską bazujacca na strukturach grodowo-terytorialnych. Rola pionierów urbanizacji ziem ruskich należała się starym ośrodkom stołecznym i grodowym, prędko jednak straciły one swoje specjalne

${ }^{20}$ A. Gilewicz, Stanowisko i działalność gospodarcza Wtadystawa Opolczyka na Rusi w latach 1372-1378, Lwów 1929, s. 17 nn.; M. Patkaniowski, Polityka miejska Kazimierza Wielkiego, „Sprawozdania z Czynności i Posiedzeń Polskiej Akademii Umiejętności" 43, 1938, nr 3, s. 86-91; W. Dworzaczek, dz. cyt., s. 78 nn.; H.W. Skorek, $Z$ dziejów polityki miejskiej na Rusi Czerwonej w poczatkach władztwa Jagiellonów (1387-1395), „Acta Universitatis Lodziensis. Zeszyty Naukowe Uniwersytetu Łódzkiego", Nauki Humanistyczno-Społeczne, ser. I, z. 29, 1978, s. 89-108; A. Berdecka, Lokacje i zagospodarowanie miast królewskich w Małopolsce za Kazimierza Wielkiego (1333-1370), Wrocław 1982; F. Sikora, Ropczycki zespót osadniczy w średniowieczu. $Z$ badań nad kazimierzowskim modelem osadniczo-urbanizacyjnym, „Teki Krakowskie” 3, 1996, s. 73-96; zob. też B. Zientara, Z dziejów organizacji rynku w średniowieczu: ekonomiczne podtoże „weichbildów” w arcybiskupstwie magdeburskim i na Ślasku w X1I-XIII wieku, PH, t. 64, 1973, z. 4, s. 681-696; S. Gawlas, O ksztatt zjednoczonego Królestwa. Niemieckie władztwo terytorialne a geneza społecznoustrojowej odrębności Polski, Warszawa 1996, s. 53 nn., 88 nn.; tenże, Uwagi o polityce miejskiej Kazimierza Wielkiego, w: Aetas media, aetas moderna. Studia ofiarowane profesorowi Henrykowi Samsonowiczowi w siedemdziesiata rocznice urodzin, red. H. Manikowska, A. Bartoszewicz, W. Fałkowski, Warszawa 2000, s. 25-41.

${ }^{21}$ Ioannis Dtugossii Annales seu cronicae incliti Regni Poloniae, lib. XI-XII: 1431-1444, Varsaviae 2001, s. 65-72; O. Halecki, Ostatnie lata Świdrygietty i sprawa wotyńska za Kazimierza Jagiellończyka, Kraków 1915, s. 38 nn.; J. Szyszka, dz. cyt. 
zadanie w ruchu lokacyjnym. Już w ostatnich latach XIV w. pojawiły się pierwsze miasta prywatne $\mathrm{w}$ osadach nielegitymujacych się żadnymi znanymi funkcjami terytorialnymi, dowodząc tym samym, że osiagnięcie magdeburgii dostępne jest nie tylko stolicom wołości.

$\mathrm{Na}$ ziemiach Rusi, poza władztwem mazowieckim, lokacje „powiatowe" nie pozostały zatem jedynymi. Wszędzie tu nie wstrzymywano urbanizacyjnych zamiarów prywatnych właścicieli, pragnących powołać w swych dobrach ośrodek miejski. Już majętność kilkuwioskowa - a zwłaszcza skupiona terytorialnie - wystarczała do organizacji miasta. Posiadanie miasteczka z targiem, kościoła parafialnego oraz dworu należało z reguły do kanonu organizacyjnego włości majątkowej możnej i bogatszej szlachty. W ten sposób doszło do lokacji miast prywatnych $\mathrm{w}$ ośrodkach niemających za sobą przeszłości grodowej: Krzywczy Krzywieckich, Buszcza Awdańców ze ślaskich Łabęd, Felsztyna Herburtów, Dubiecka i Dynowa Kmitów, Nowego Miasta Bybelskich, Rohatyna Wołczka Przesłużyca, Strzelisk Waśka i Prokopa z Tyśmienicy, Turobina Dobrogosta z Szamotuł, Petlikowiec i Michalcza Buczackich, Pruchnika Próchnickich, Krakowca Mikołaja i Steczka z Tarnawy, Jaćmierza Fryderyka Jacimirskiego, Pomorzan Świnków, Wojsławic Jana z Czyżowa, Krukienic Rychlików, Kańczugi Pileckich i następnych miast szlacheckich i możnowładczych ${ }^{22}$. Niektóre czekała zmiana własnościowa. Na przykład Rachanie, najpierw lokowane w księstwie bełskim jako ośrodek książęcy, przeszły w ręce prywatne, natomiast Kamionka w ziemi lwowskiej, lokowana zapewne przez Floriana z Korytnicy, przeszła z kolei do domeny królewskiej. Podobna drogę przebył Sambor w ziemi przemyskiej. Lokowane zostały również miasta biskupie: Brzozów i Radymno biskupów przemyskich, Dunajów arcybiskupów lwowskich, Skierbieszów, Sawin, Kumów i Pawłów biskupów chełmskich. Przypadki Rymanowa lokowanego przez Władysława Opolczyka i wkrótce nadanego Dymitrowi bądź Iwonowi z Goraja, Zarszyna nadanego jako miasto królewskie Jachnikowi Dzieweczce ze Sosweszowa (choć kilka lat wcześniej wystapił on już jako właściciel tej osady) oraz Buszcza, w którym przez pewien czas utrzymywał się własnościowy dualizm królewsko-szlachecki, są trudne do zinterpretowania, ponieważ ich lokacje sa bliskie w czasie z nadaniem, a dla dwóch ostatnich miast $\mathrm{w}$ dodatku nierozpoznane.

${ }_{22}$ Zob. M. Horn, Miejski ruch osadniczy..., s. 59 nn.; A. Janeczek, Faktorie..., s. $435 \mathrm{nn}$. Ostatnio Marian Wolski zaproponował cofnięcie daty lokacji Pruchnika (przed 1424 r.) na okres poprzedzający 1397 r.; zob. tenże, Dzieje Pruchnika $i$ okolic do końca XVI wieku, w: Pruchnik. Studia z dziejów miasta i okolic, red. M. Wolski, Kraków 2014, s. $67 \mathrm{nn}$. 
Ten drugi typ umiastowienia można hasłowo objąc mianem urbanizacji dominialnej, służył bowiem potrzebom własności szlacheckiej, stabilizującej się na ziemiach ruskich w rezultacie akcji donacyjnej prowadzonej przez panujacych, kolonizacji wewnętrznej i w pewnym zakresie reformy czynszowej. Czas na pojawienie się i spełnienie tych potrzeb nieprzypadkowo zbiegł się z zakończeniem formowania majątków szlacheckich i wykrystalizowaniem lokalnych ośrodków, pełniących funkcje centralne. Program powołania miasta służącego integracji świeżo stworzonych włości majątkowych, stanowiącego ośrodek administracyjny i gospodarczy, religijny, nierzadko i kulturalny, a także zaspokajającego potrzeby prestiżowe, będącego rezydencja pańska, nie stał w sprzeczności z inną pobudka, z poszukiwaniem nowych źródeł dochodów, których można było się spodziewać po funkcjach komunikacyjnych, usługowych i handlowych spełnianych przez ośrodki miejskie. Te właśnie potrzeby i oczekiwania, o bardziej powszechnym zasięgu, dostrzegalne wcześniej na ziemiach polskich ${ }^{23}$, dały w efekcie specjalny typ urbanistyczny - małego miasta prywatnego, tak charakterystyczny dla Europy Środkowo-Wschodniej i niektórych innych części kontynentu ${ }^{24}$.

Narastanie lokacji prywatnych i zagęszczanie się sieci miast szlacheckich i kościelnych czytelnie prezentuje się na mapach, które rejestruja ten proces w kilku etapach (zob. mapy 1-4). Ich cezury zostały obrane odpowiednio do lat panowań, a więc do 1379 r. (panowanie Kazimierza Wielkiego i okres sprawowania władzy przez Władysława Opolczyka), do 1434 r. (epizod bezpośrednich rządów węgierskich, przerwany wyprawa Jadwigi w 1387 r., a przede wszystkim panowanie Jagiełły), do 1444 r. (panowanie Władysława III) i wreszcie do roku 1500, na którym niniejszy przegląd się zamyka. Charakteryzując na ich podstawie proces wypełniania się sieci miast prywatnych, można od razu dostrzec, że przybierał on kształt fali rozlewającej się stopniowo z zachodu na wschód i północ kraju.

${ }^{23}$ A. Wyrobisz, Rola miast prywatnych $w$ Polsce XVI $i$ XVII wieku, PH, t. 65, 1974, z. 1, s. 19-46; tenże, Małe miasta w Polsce w XVI i XVII w., w: Miasta doby feudalnej $w$ Europie Środkowo-Wschodniej. Przemiany społeczne a uktady przestrzenne, red. A. Gieysztor, T. Rosłanowski, Warszawa 1976, s. 177-187; tenże, Miasta prywatne $w$ Polsce XVI-XVIII $w$. jako inwestycje kulturalne, KHKM, t. 26, 1978, nr 1, s. 47-56; tenże, Typy funkcjonalne miast polskich $w$ XVI-XVIII w., PH, t. 72, 1981, z. 1, s. 25-49; T. Lalik, Funkcje miast $i$ miasteczek $w$ Polsce późniejszego średniowiecza, KHKM, t. 23, 1975, nr 4, s. 551-565; tenże, Geneza sieci miasteczek w Polsce średniowiecznej, w: Miasta doby feudalnej..., s. 113-136.

${ }^{24} \mathrm{H}$. Samsonowicz, Małe miasto $w$ środkowej Europie późnego średniowiecza. Próba modelu, RDSG, t. 50, 1989, s. 31-44; A. Bartoszewicz, Miasto czy wieś? Małe miasta polskie w późnym średniowieczu, PH, t. 99, 2008, z. 1, s. 121-136. 
Mapa 1. Miasta prywatne lokowane do 1379 r.

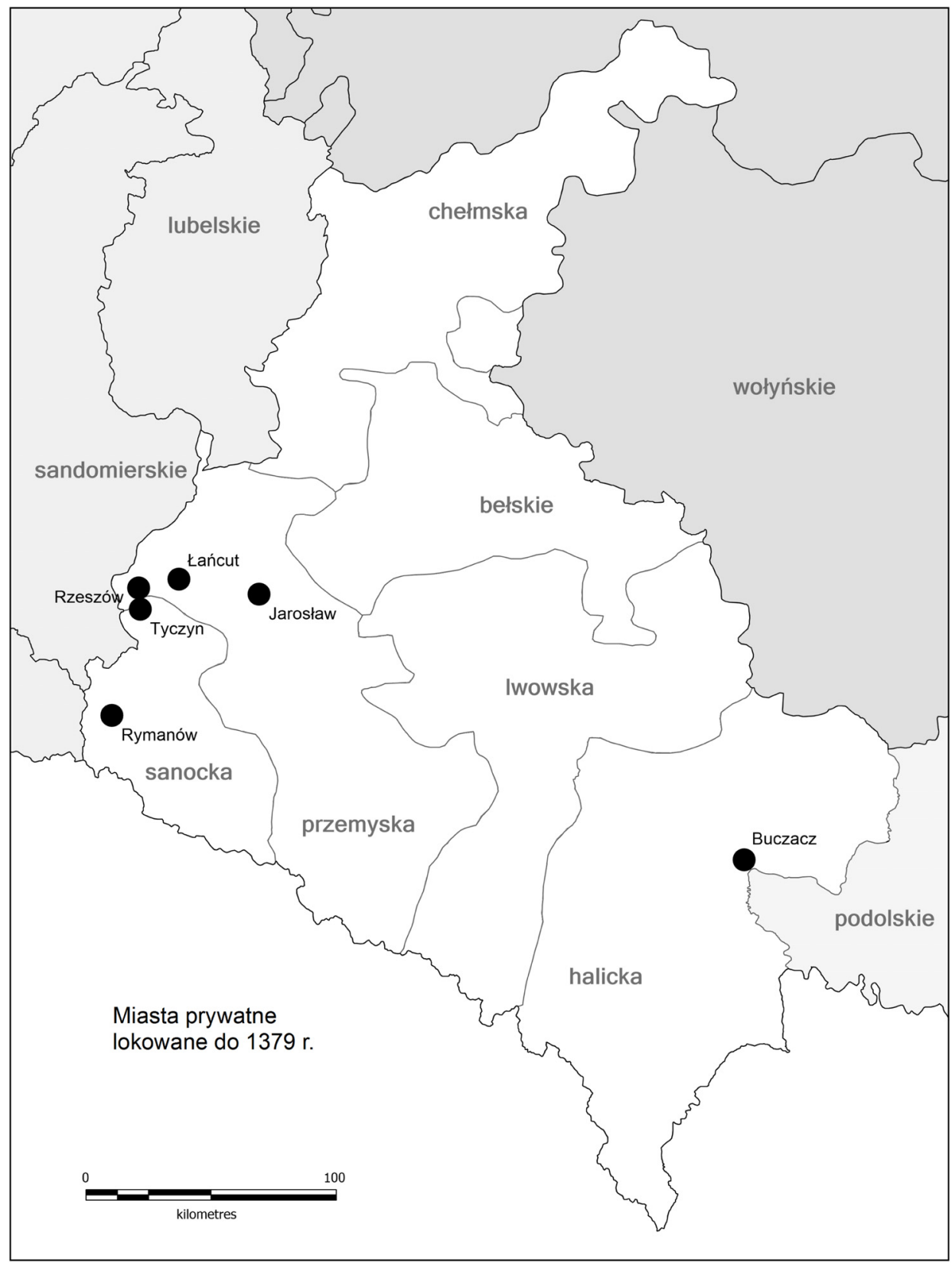


Mapa 2. Miasta prywatne lokowane do $1434 \mathrm{r}$.

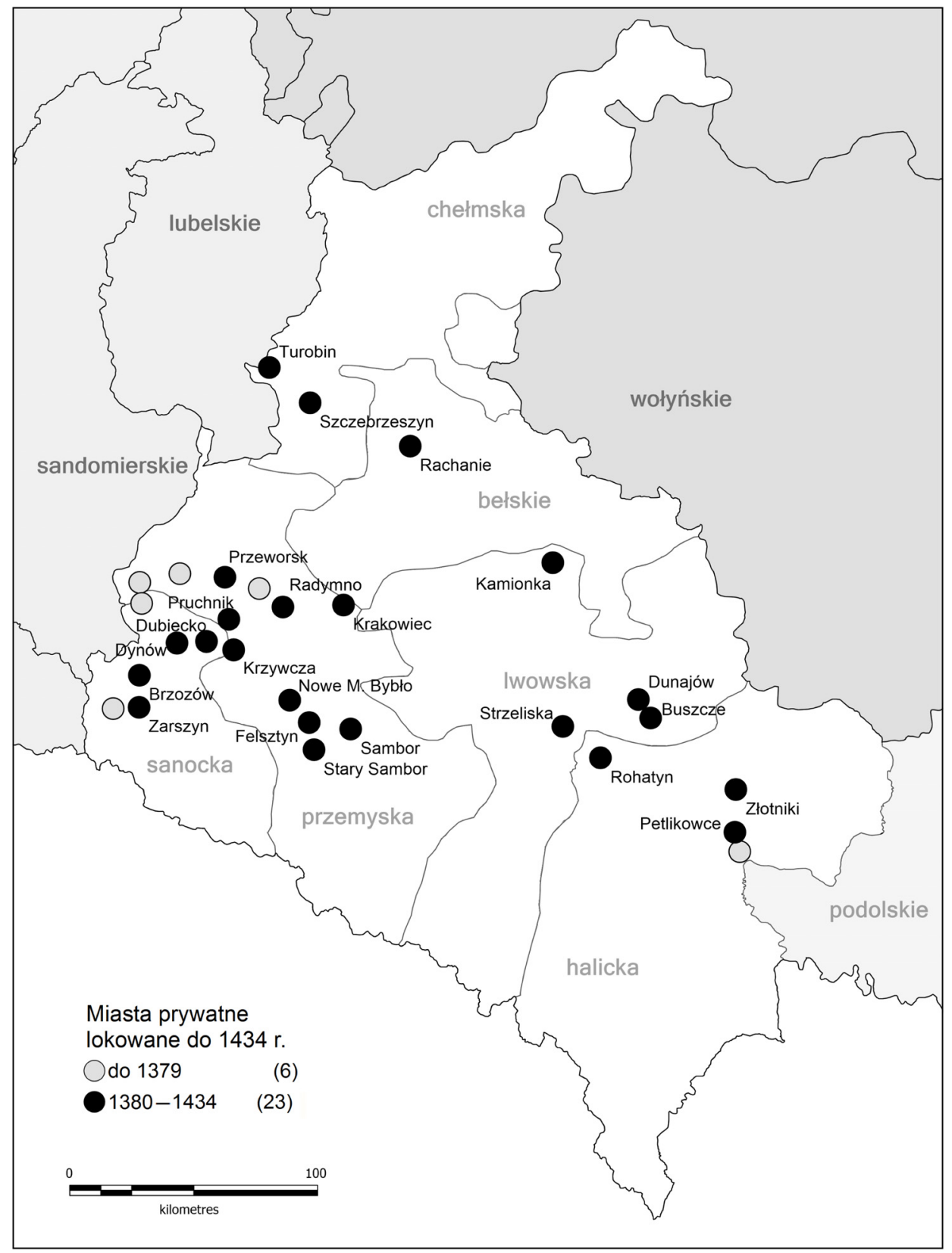


Mapa 3. Miasta prywatne lokowane do $1444 \mathrm{r}$.

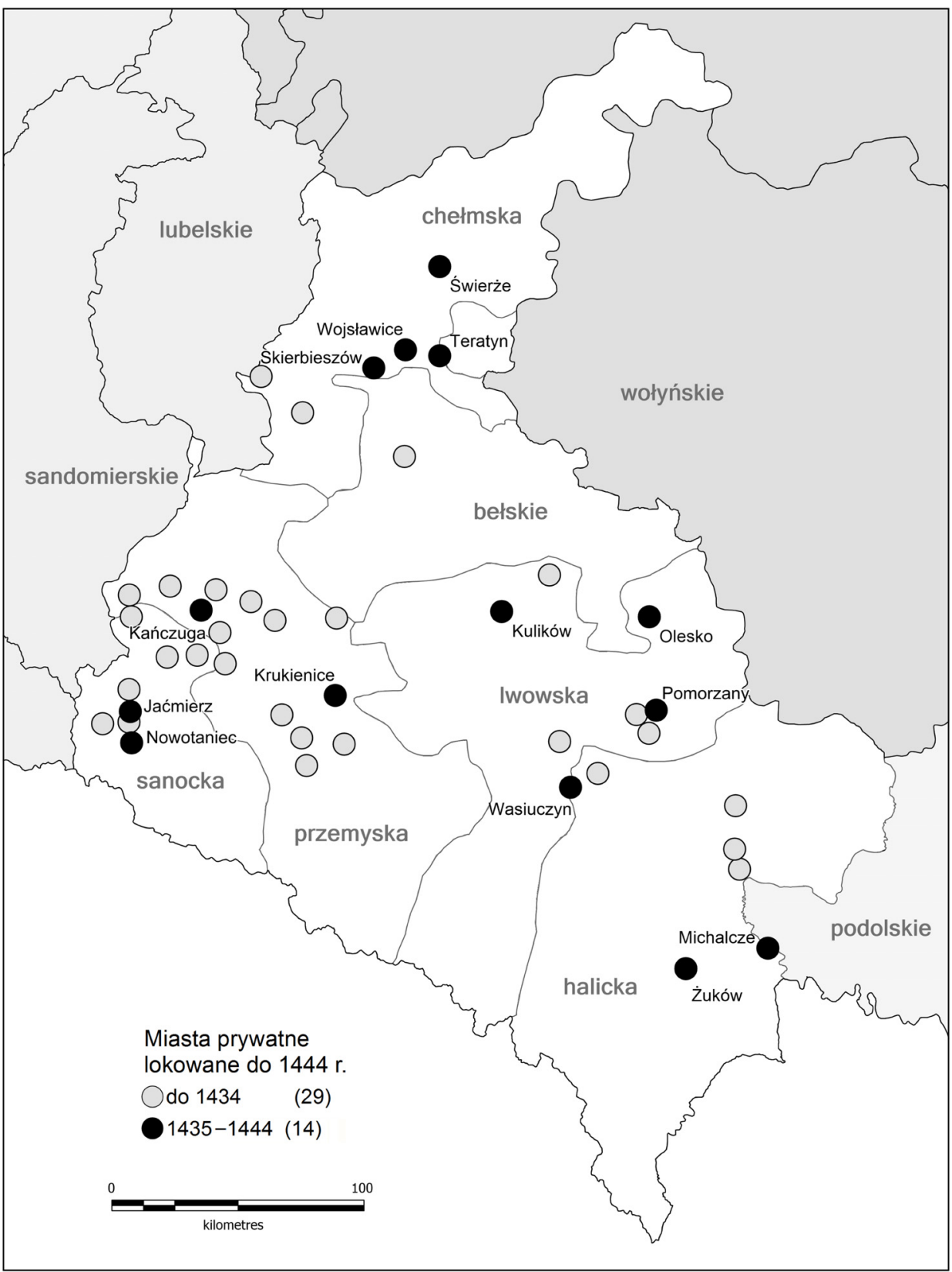


Mapa 4. Miasta prywatne lokowane do $1500 \mathrm{r}$.

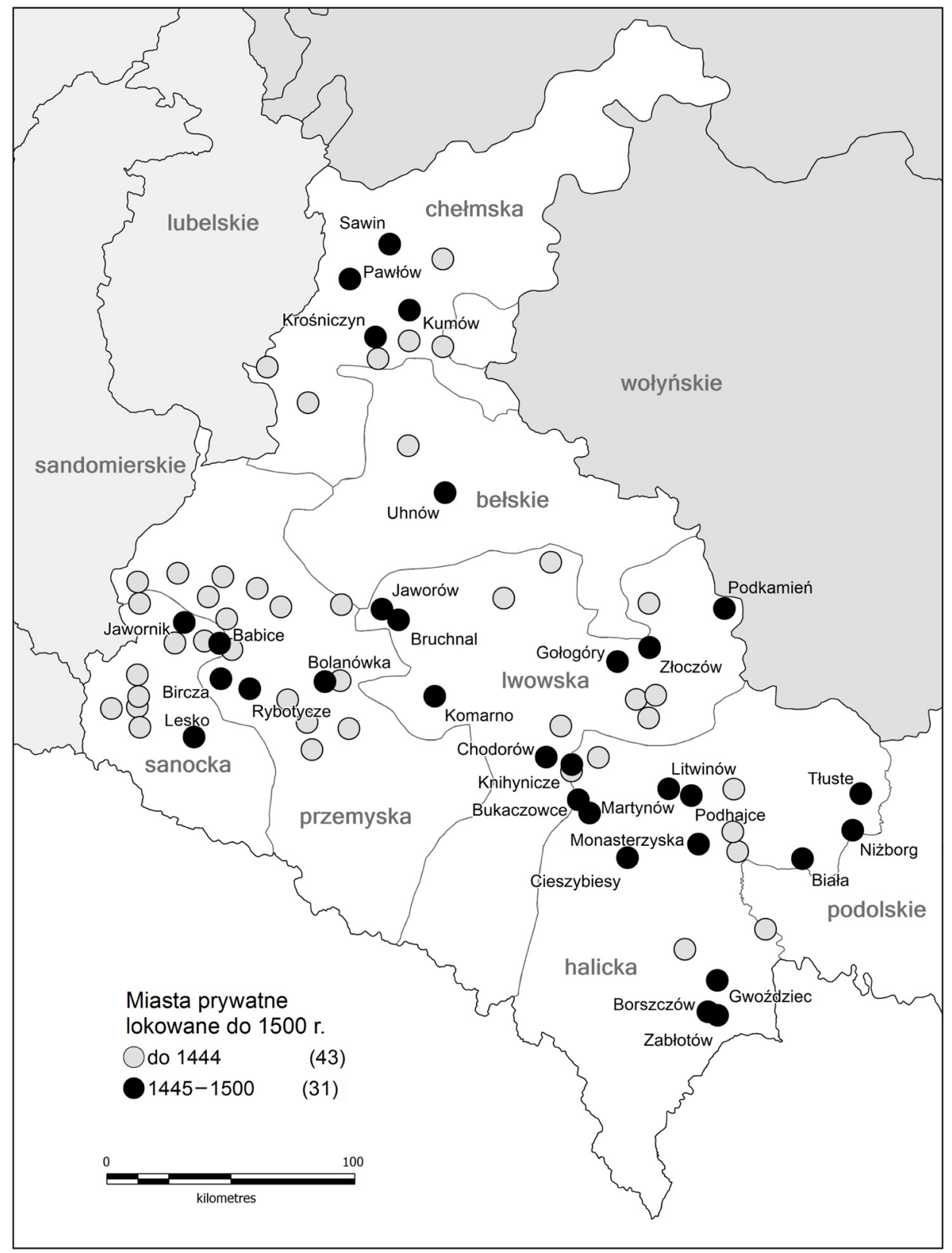


Potrzeba prywatnych lokacji pojawiła się najpierw w zachodniej części Rusi, w ziemi sanockiej i przemyskiej, regionie intensywnie kolonizowanym, bliższym ziemiom polskim i w wydatniejszy sposób korzystającym z migracji ludnościowych, przemieszczających się z Zachodu, ze Ślaska i Małopolski, na wschód. W okresie przedjagiellońskim wszystkie inicjatywy skupiły się na tym terenie, a jedynym wyjątkiem był Buczacz Awdańców, leżący na przeciwległym, wschodnim krańcu Rusi (zob. mapa 1). Dominacja tego regionu umocniła się jeszcze w okresie panowania Władysława Jagiełły, choć wtedy zaczęły się w ten proces włączać inne ziemie, położone na północ i wschód od przemysko-sanockiego matecznika (zob. mapa 2). W dziesięcioleciu panowania Władysława Warneńczyka daje się zauważyć zrównoważenie i zbliżony rozkład zakładanych wówczas miast prywatnych pomiędzy poszczególnymi ziemiami, jednak z wyjątkiem ziemi bełskiej, nadal ich pozbawionej (zob. mapa 3). W okresie ostatnim, przypadającym na panowanie Kazimierza Jagiellończyka i Jana Olbrachta, nowe miasta prywatne pojawiaja się we wszystkich ziemiach, lecz najwięcej ich powstaje we wschodniej części Rusi Koronnej (zob. mapa 4). Początkowa dysproporcja nasycenia lokacjami nie trwała więc długo i została zniwelowana. W XVI w. nowe akcje miastotwórcze koncentrowały się we wschodniej połaci ziemi lwowskiej i w ziemi halickiej, w ziemiach przemyskiej i sanockiej już ich wówczas brakowało.

Rozlokowanie w przestrzeni miast różnych typów własnościowych, rozpatrywane $\mathrm{w}$ momencie końcowym dla tych analiz (1500), wykazuje nierównomierności i cechy regionalne. Przewaga miast prywatnych mocno uwydatnia się na zachodzie, zwłaszcza w ziemi sanockiej. Drugim biegunem jest województwo bełskie z jednym tylko miastem prywatnym i drugim, pierwotnie, w czasie lokacji, książęcym (Rachanie). Z kolei ziemia chełmska odróżnia się największą liczbą miast kościelnych, biskupich. Geografia miast różnych typów własności zależała naturalnie od rozmieszczenia samych majętności, w ziemi bełskiej zaś dodatkowo zaważyła na niej polityka mazowieckich Piastów.

Daje o sobie znać jeszcze inna, generalna dysproporcja zaangażowania własności królewskiej i prywatnej w miejski ruch osadniczy. Przywoływana wyżej liczba ośrodków należących około 1500 r. do króla (48) oraz do szlachty i Kościoła (69) daje odpowiednio odsetek 41 i 59\%. Tymczasem ogólna struktura własności ziemskiej w drugiej połowie XV w. wykazuje zupełnie inny stosunek: dla województwa bełskiego 18\% (dobra królewskie) względem 82\% (dobra prywatne), 
dla ziemi sanockiej odpowiednio 20 i 80\%, dla ziemi lwowskiej 28 i $72 \%^{25}$. Okazuje się, że stopień udziału własności prywatnej w umiastowieniu prowincji ustępował znacznie jej stanowi posiadania. Nie znamy co prawda analogicznych szacunków dla tego czasu z innych ziem Rusi ${ }^{26}$, lecz nawet ta częściowa konfrontacja ujawnia znacząco niższy wymiar urbanizacji włości prywatnych niż domeny w późnym średniowieczu. Na tym tle dobrze zrozumiałe staje się natężenie ruchu lokacyjnego w dobrach szlacheckich w XVI w. i jego spowolnienie w dobrach monarszych - oba zjawiska zapowiadające się już w drugiej połowie XV w.

Słabością lub nawet brakiem zurbanizowania - bez względu na charakter własności ziemskiej, królewskiej czy prywatnej - odznaczały się strefy rzadkiego osadnictwa, których zapóźnienie gospodarcze było uwarunkowane środowiskowo: pasmo karpackie z jego przedgórzem, ciagnące się wzdłuż południowego skraju Rusi, górzysty i gęsto zalesiony wał Roztocza przebiegajacy na styku ziemi przemyskiej, chełmskiej, bełskiej i lwowskiej, strefa „wodnego lasu” pomiędzy ziemią bełską i lwowska, poleska, północno-wschodnia część ziemi chełmskiej. Do zagospodarowania tych peryferii osadniczych, obejmującego także budowę nowych miast, przystapiono w XVI-XVII w.

Ruch lokacyjny odznaczał się wielką skutecznościa. Niemal wszystkie inicjatywy zakończyły się powodzeniem. Zaledwie pięć lokacji prywatnych zalicza się do nieudanych. Fiaskiem skończył się zamysł arcybiskupa lwowskiego w przypadku Bartatowa (przy Bartoldowej karczmie na gościńcu lwowsko-przemyskim) w ziemi lwowskiej ${ }^{27}$, lokowania Porchowej przez Buczackich w ziemi halickiej ${ }^{28}$, Smolna przez Oleskich

25 A. Fastnacht, Osadnictwo ziemi sanockiej w latach 1340-1650, Wrocław 1962, s. 82; A. Janeczek, Polska ekspansja osadnicza $w$ ziemi lwowskiej $w$ XIV-XVI wieku, PH, t. 69, 1978, z. 4, s. 611; tenże, Osadnictwo pogranicza..., s. 115.

${ }^{26}$ Można się spodziewać, że sytuacja w ziemi przemyskiej była bardziej korzystna dla królewszczyzn, utrzymały one tutaj zapewne najwyższy w skali Rusi udział w strukturze własności ziemskiej; w końcu XVI w. do króla należało 33\% osad, do szlachty 61\%; zob. E. Trzyna, Własność feudalna ziemi przemyskiej od połowy XVI do poczatków XVIII w., „Sprawozdania Wrocławskiego Towarzystwa Naukowego”, series A, nr 31, 1976, s. 39-41; tenże, Ziemia sanocka i struktura jej wtasności feudalnej od połowy XVI do drugiej połowy XVII wieku, „Rocznik Województwa Rzeszowskiego" 9, 1978, s. 145-184.

${ }^{27}$ W 1442 r. Władysław Warneńczyk zezwolił Janowi Odrowążowi, arcybiskupowi lwowskiemu, założyć miasto; zob. AGZ, t. 2, Lwów 1870, nr 66.

${ }^{28}$ W 1476 r. została odnotowana jako opidum; zob. AGZ, t. 19, wyd. A. Prochaska, Lwów 1906, nr 1515; później występuje jako wieś prawa ruskiego. Brak układu regularnego. 
w ziemi lwowskiejej9 i Uchań przez Jasieńskich ${ }^{30}$. Przypadek Bachórza Kmitów, w którym sa ślady życia miejskiego już w 1391 r., później niewidoczne, to raczej translacja ośrodka do pobliskiego Dynowa, lokowanego skutecznie niedługo potem ${ }^{31}$. W nielicznych przypadkach lokacja zakończyła się połowicznym, wątpliwym bądź nietrwałym sukcesem, w postaci osad o niepewnym statusie miejskim (np. Krakowiec w ziemi przemyskiej); śladem widocznych już u współczesnych wahań jest chwiejne w źródłach kwalifikowanie ich jako miast bąź wsi. Szczególnie degradujacy wpływ miały notoryczne najazdy nieprzyjacielskie, zwłaszcza gdy ich skutki nie zostały przezwyciężone pomyślna rekonstrukcją ośrodka.

\section{Pozycja miast prywatnych w sieci miejskiej Rusi Koronnej}

Przegląd chronologii ruchu lokacyjnego w dobrach prywatnych nie uwzględnia aspektu jakości urbanizacji, rozmiaru i postaci jej efektów, a więc uformowania miast o różnej skali założeń, różnej wielkości, o zróżnicowanym potencjale gospodarczym i stopniu intensywności życia miejskiego, o odmiennych funkcjach, niekoniecznie typowo miejskich. Formujący się w późnym średniowieczu krajobraz miejski Rusi cechowała jednolitość ustrojowa, lecz tworzące go ośrodki dzieliła spora różnorodność wielkości, znaczenia i spełnianej roli.

Możliwości sklasyfikowania miast według ich wielkości znacznie z reguły ogranicza charakter dostępnych źródeł z epoki. Nie przynoszą one danych bezpośrednich, a więc liczby domów czy liczby mieszkańców, które dałyby się zestawić i porównać. Brak ten próbuje się przezwyciężać w badaniach, wykorzystując rozmaite wskaźniki pośrednie, rozpoznając tzw. dojrzałość społeczną (stopień rozwoju według różnych symptomów) i przeprowadzając analizę funkcjonalną miast, poprzez przypisanie im roli ośrodków krajowych,

${ }_{29}$ W latach 1493-1494 występuje jako oppidum, ma zapłacić szos; zob. AGZ, t. 15, wyd. A. Prochaska, Lwów 1891, nr 2328, 2417. Nie wytworzył się tu miejski układ przestrzenny.

${ }^{30}$ R. Szczygieł, Rola przywilejów lokacyjnych $w$ procesie lokacji miast $w X V$ -XVII w. na przykładzie Uchań, „Rocznik Lubelski” 27/28, 1985/1986, s. 51-59; tenże, Kłopoty $z$ umiastowieniem Uchań. Proces lokacyjny $w$ latach 1484-1603, w: Dzieje Uchań 1484-2006, red. K. Spaleniec, Uchanie-Lublin 2006, s. 29-37.

${ }^{31}$ G. Klebowicz, Organizacja parafialna diecezji przemyskiej obrzadku łacińskiego $w$ XIV-XVI wieku, Lublin 2013, s. 170. 
regionalnych, lokalnych bądź wyłącznie miejscowych, czyli naczelnych osad małych włości ${ }^{32}$.

Szukając mierzalnych kryteriów różnicujących miasta Rusi, sięgnięto po materiały podatkowe z pierwszych dziesięcioleci XVI w., mianowicie rejestry szosu i czopowego. Maja one dobrze znane wady, typowe dla źródeł fiskalnych, a także te wynikajace $\mathrm{z}$ ewolucji dawnych średniowiecznych świadczeń w epoce nowożytnej i utraty ich pierwotnego charakteru. Szos królewski ${ }^{33}$, podatek od majątku mieszczan, został odrzucony jako podstawa dla szacunków demograficznych lub jest co najmniej nieufnie traktowany w tej roli, przynosi bowiem wartość wynikająca nie tylko z liczby rodzin, ale również z ich zamożności; inną ułomnościa jest jego postępujace zryczałtowanie ${ }^{34}$. Na początku XVI w. nie było to jednak zjawisko w pełni już ugruntowane, uniwersały poborowe określały obowiązujace stawki podatkowe dla wymienianych kategorii płatników, sugerując ich realne naliczanie, jako świadczenie mieszczan, a nie miasta ${ }^{35}$. Podtrzymuje to przypuszczenie

${ }^{32}$ Tak w syntezie M. Boguckiej i H. Samsonowicza, dz. cyt., s. 106 nn. Nieunikniona niedogodnościa tej metody jest spora doza arbitralności przeprowadzonych zaszeregowań, zwłaszcza jeśli nie wspiera jej inne, dodatkowe kryterium różnicujace, $\mathrm{np}$. dane o podatku koronacyjnym, liczbie zbrojnych wystawianych na wojnę pruska; zob. J. Wiesiołowski, Sieć miejska $w$ Wielkopolsce $w$ XIII-XVI wieku. Przestrzeń $i$ społeczeństwo, KHKM, t. 29, 1980, nr 3, s. 385-299. Tak jest właśnie w przypadku przypisanych do czterech grup miast Rusi. Anonsowana tam pomocniczo lista 39 miast ruskich zobowiązanych do świadczeń na wyprawę turecką w 1484 r. (AGAD, Metryka Koronna, ks. 13, k. 32v) to w rzeczywistości wykaz zapewne stacji królewskich, obejmujący wyłącznie ośrodki domeny, do klasyfikacji nieprzydatna.

${ }^{33}$ S. Kutrzeba, Szos królewski w Polsce w XIV i XV wieku, „Przegląd Polski” 34, 1899, nr 135, s. 78-103, 270-290; tenże, Finanse Krakowa w wiekach średnich, „Rocznik Krakowski” 3, 1900, s. 73-88; T. Brzeczkowski, Ustanawianie podatków nadzwyczajnych w Polsce $w$ XV w., RDSG, t. 42, 1981, s. 77-106; M. Ludwig, Besteuerung und Verpfändung königlicher Städte im spätmittelalterlichen Polen, Berlin 1984, s. 44 nn.; M. Goliński, Wokół socjotopografii późnośredniowiecznej Legnicy. Część I, Wrocław 2000 (Acta Universitatis Wratislaviensis, 2203), s. $25 \mathrm{nn}$.

${ }^{34}$ I. Gieysztorowa, Wstęp do demografii staropolskiej, Warszawa 1976, s. 166, 183 n.; zob. też M. Bogucka, H. Samsonowicz, dz. cyt., s. 358 nn.; K. Boroda, Przeszłość i przyszłość przeliczników demograficznych dla XVI-wiecznych źródet podatkowych, https://www.academia.edu/18501362 (20 VII 2016), w obu pracach przedstawiona długa już dyskusja i podejmowane rozmaite próby metodyczne.

35 Stawki szosu według uniwersału 1507 r. wynoszą 2 gr od grzywny majątku ruchomego i nieruchomego kupca i rzemieślnika oraz 4 gr od głowy w przypadku ludzi luźnych, służby i komorników; czopowe, pobierane od wyrobu i wyszynku, ma wyznaczone różne stawki dla piwa, miodu i wina, podzielonego z kolei na kilka gatunków; zob. AGAD, Archiwum Skarbu Koronnego (dalej: ASK), I 20, k. 51ㄴ-52. Uniwersał poboru (szos pojedynczy według starych kwitów) i czopowego z 1526 r.; zob. Corpus iuris Polonici, t. 4, wyd. O. Balzer, Cracoviae 1910, nr 63, 64. 
także i to, że wymiar szosu dla poszczególnych miast nie był stały, ulegał pewnym wahaniom w kolejnych poborach, chociaż okragłe sumy płacone przez niektóre miasta zdają się już wskazywać na ustalenie $\mathrm{z}$ góry wymaganej od nich kwoty, np. 250 grzywien ze Lwowa w 1526 r. (w 1507 r. zwolniony) czy 60 i 50 grzywien z Przemyśla odpowiednio w 1507 i 1526 r. Zachowany w archiwum miejskim szczegółowy rejestr szosu przemyskiego z 1527 r., wyliczający konkretnych płatników i ich zróżnicowane wartościowo wpłaty, został przez poborcę podsumowany w łącznej wysokości 66 grzywien i $5 \mathrm{gr}^{36}$. Nie jest to więc suma mocno odbiegajaca od podatku uiszczonego przez miasto w poprzednim roku, a już bardzo bliska temu z 1507 r. Podobnie wpłata lwowska nie jest oderwana od wartości zbieranego szosu, który znamy ze szczegółowych również rejestrów miejskich z lat 1536, 1538 i 1540; oscylował on wówczas w granicach 295-320-365 florenów, czyli 185-200-230 grzywien (dodajmy przy tym, że Lwów przeżył w 1527 r. ogromny pożar, co mogłoby tłumaczyć różnicę wobec roku 1526, a też i stopniowy wzrost w kolejnych latach, wraz z odbudowa) ${ }^{37}$. Wielkość wpłat obu miast znajduje zatem niezłe oparcie w udokumentowanej kolekcie. Wobec tego zdecydowano się udzielić szosowi ograniczonego kredytu zaufania i rozpatrzyć płynące stąd informacje, uznawszy, że choć nie znamy mechanizmu naliczania względnie określania wielkości oczekiwanej przez skarb daniny ${ }^{38}$, to możemy założyć, iż nie był on w pierwszych jeszcze dziesięcioleciach XVI w. świadczeniem całkowicie dowolnie ustalanym, niezwiązanym z sytuacją majątkową miejskiej społeczności.

Z kolei czopowe, zasadniczo królewskie, ale także mające swój odpowiednik miejski, pośredni podatek akcyzowy od wyrobu oraz sprzedaży napojów alkoholowych, zawiera $\mathrm{w}$ sobie podwójną informację:

36 „Exactio contribucionis taxe integre alias szoschu laudi Cracoviensis a Dominica Iudica exigi incepta 1527”; AP w Przemyślu, Akta miasta Przemyśla, 301, s. 15-23. Uniwersał poboru uchwalonego na sejmie krakowskim 1527 r.; zob. Acta Tomiciana, t. 9, wyd. Z. Celichowski, Posnaniae 1876, nr 74 (pełna rata szosu wyznaczona na tę niedzielę, $1 / 2 \mathrm{w}$ drugiej racie po pięciu miesiącach).

${ }^{37}$ Rata na „exactio civilis” i druga na „exactio Sacre Maiestatis Regie”, obie o równej wartości, według podliczenia poborcy; zob. Central’nyj Deržavnyj Istoryčnyj Archiv Ukrainy u m. L'vovi, fond 52, opis 2, spr. 769, s. 30-97.

38 Sprawę dodatkowo komplikuje inna niż określana w uniwersałach stopa szosu lwowskiego, obojętnie, czy przeznaczonego na potrzeby własne, czy państwa; kwestia wymaga wnikliwego zbadania. W XVII w. suma szosu królewskiego, przekształconego w kontyngent, była z reguły niższa niż suma zebranego szosu miejskiego; nadwyżkę zatrzymywało miasto; zob. R. Zubyk, Gospodarka finansowa miasta Lwowa w latach 1624-1635, „Badania z Dziejów Społecznych i Gospodarczych” 7, 1930, s. 174 nn., $189 \mathrm{nn}$. 
o wymiarze konsumpcji ludności oraz wymiarze produkcji w mieście powszechnego produktu spożywczego, czyli piwa, które miało dominujący udział $\mathrm{w}$ świadczeniu. $\mathrm{W}$ tym przypadku tym bardziej nie ma obawy o jego zryczałtowanie, przeczą temu zarówno wahania kwartalne wpłat, jak i zachowane szczegółowe rejestry z poszczególnych miast, wyliczające konkretnych płatników i ich obciążenia. Pod tym względem czopowe wydaje się bardziej miarodajne niż szos. Obie serie danych, dostarczane przez rejestry szosu i czopowego, wykorzystane wprost, bez prób ich wciagnięcia do dalszych, ryzykownych kalkulacji, w tym do wątpliwych przeliczeń mających przynieść dane demograficzne, można traktować jako orientacyjne przynajmniej, skumulowane wskaźniki liczebności, zamożności, konsumpcji ludności miejskiej oraz mocy produkcyjnej miasta w jednej, ale powszechnej gałęzi wytwórczości.

Do zestawienia prezentujacego wpływy z szosu i czopowego miast Rusi wybrane zostały rejestry $\mathrm{z}$ dwóch oddalonych od siebie czasowo serii, z lat 1507 i 1526. Chodziło o uniknięcie zakłócenia uzyskanego obrazu przypadkowymi, jednorazowymi odstępstwami. Nie dla wszystkich z sześciu ziem udało się zebrać dane dokładnie z tych lat. Winny był temu nie tylko brak rejestru $\mathrm{z}$ obranego roku, ale również znaczna niekompletność istniejącego, co wynikało z często przyznawanych ulg i zwolnień, po licznych najazdach tatarskich, tureckich i wołoskich czy pożarach, bądź z uzyskanego przywileju na przeznaczenie bieżącego wpływu na własne potrzeby miasta (pro reformatione, pro municione). Niektóre rejestry czopowego, wtedy gdy było ono wydzierżawiane, sa nieprzydatne, podaja bowiem wpływy łącznie dla kilku miast wraz $\mathrm{z}$ wsiami. W takich przypadkach posiłkowano się rejestrami z kolejnych lat: z 1510 r. dla ziemi lwowskiej i chełmskiej, z 1515 r. dla halickiej, w drugiej zaś serii rejestrami szosu z $1531 \mathrm{r}$. i czopowego z $1542 \mathrm{r}$. dla ziemi chełmskiej i województwa bełskiego ${ }^{39}$. Nie udało się natomiast uzyskać danych szosu ziemi halickiej oraz czopowego ziemi chełmskiej dla pierwszej serii. Duża część miast nie uzyskała tu jednak reprezentacji, korzystały one bowiem z ustawicznie udzielanych im zwolnień. Dotyczy to głównie wschodniej połaci Rusi, najbardziej narażonej na zniszczenia najazdami, i odbija się mocniej w przypadku szosu (brak danych z 47 miast) niż czopowego (brak danych z 21 miast). Ta ostatnia danina przynosiła większe dochody skarbowe i mniej chętniej z niej

${ }^{39}$ Czopowe ziemi halickiej z 1515 r. oraz szos województwa bełskiego z $1531 \mathrm{r}$. zostały wydane; zob. Polska XVI wieku pod względem geograficzno-statystycznym, t. 7, cz. 1: Ziemie ruskie. Ruś Czerwona, wyd. A. Jabłonowski, Warszawa 1902 (Źródła Dziejowe, 18), s. 175-176, 238-240, tu jednak wykorzystano materiał archiwalny z uwagi na zdarzajace się pomyłki edytorskie. 
rezygnowano. Zupełnie nieobecnych jest $\mathrm{w}$ zestawieniu aż 16 miast ziemi halickiej i 3 ziemi chełmskiej, z pozostałych ziem dysponujemy danymi dla wszystkich lub niemal wszystkich ośrodków, przynajmniej częściowymi.

W zestawieniu uwzględniono pełną ratę szosu zsumowaną $\mathrm{z}$ jego składników oraz roczne, również zsumowane wpływy z czopowego, wybieranego kwartalnie. W przypadkach, gdy brakowało danych o nim z części roku, kwotę roczną ekstrapolowano, doliczając średnie z pozostałych kwartałów. Wszystkie kwoty, podawane w grzywnach, kopach, florenach i groszach, przeliczono na grosze. Tak ujednolicone dane zostały zebrane na wykresach $2-7$.

Wymierny liczbowo ciag danych charakteryzujacych miasta pozwala na przeprowadzenie klasyfikacji ułatwiającej dalsze analizy, wyróżnianie i porównywanie. Przyjęto klasyfikację pięciostopniowa, zdecydowanie użyteczniejszą i lepiej ilustrująca rozwarstwienie ośrodków. Przedziały między kategoriami zostały wyznaczone metodą tzw. naturalnego podziału (na podstawie metody Jenksa), wyszukującej takie wartości graniczne, które najlepiej oddawałyby rzeczywiste różnice pomiędzy miastami (maksymalizacja różnic między kategoriami i minimalizacja w obrębie kategorii). Nie zostały więc dobrane arbitralnie, lecz tak, by mogły najlepiej reprezentować istniejace pośród miast zróżnicowanie. Progi klasyfikacji podaje poniższe zestawienie:

$\begin{array}{rrr}\text { szos powyżej } 12000 \mathrm{gr} & \text { czopowe powyżej } 20000 \mathrm{gr} & \text { kategoria I } \\ 1500 \mathrm{gr} & 3900 \mathrm{gr} & \mathrm{II} \\ 600 \mathrm{gr} & 1800 \mathrm{gr} & \mathrm{III} \\ 300 \mathrm{gr} & 500 \mathrm{gr} & \mathrm{IV} \\ 1 \mathrm{gr} & 1 \mathrm{gr} & \mathrm{V}\end{array}$

Obie niezależne od siebie klasyfikacje, według szosu i według czopowego, wykazały w swoich rezultatach zadowalajaca korelację. Większość miast uzyskała analogiczna kategorię w obu seriach danych. Jedynie w 14 przypadkach (na 105) inną kategorię wyznaczyło miastu czopowe, a inna szos (np. V według szosu, IV według czopowego). Sa to rozbieżności jednego stopnia, niewprowadzające istotnego dysonansu między grupowaniami przeprowadzonymi obydwoma sposobami.

Wykaz zestawiony dla ziemi przemyskiej (zob. wykres 2) pokazuje zróżnicowaną strukturę tutejszych miast, wypełnioną dość równo przez ośrodki różnej rangi. Są wśród nich takie, które można opatrzyć mianem ośrodka większego w skali regionalnej (kategoria II: Przemyśl, 
Sambor, Drohobycz; wszystkie królewskie), pamiętając przy tym, że użyta tu (i w dalszej części analizy) kwalifikacja operująca relatywnymi określeniami (miasto największe, większe, średnie, małe miasto, miasteczko, czyli kategorie I-V) zawiera w sobie nie tylko ocenę zaludnienia, ale również zamożności mieszkańców, skali konsumpcji i siły ekonomicznej miasta. Obok nich wyodrębnia się grupa miast relatywnie średnich (kategoria III), złożona z ośrodków należących do obu typów własnościowych (z miast prywatnych Jarosław, Przeworsk, oba bliskie wyższej kategorii, Rzeszów, Nowe Miasto Bybło i z trudem tu się mieszczące Łańcut oraz biskupie Radymno). Wszystkie z nich, oprócz Bybła i Radymna, miały za sobą przeszłość ośrodków grodowych i pozycje stolic powiatowych. Pozostałe to miasta małe (kategoria IV: Kańczuga, Pruchnik, Tyczyn i Felsztyn na granicy z kategorią niższa) oraz miasteczka (kategoria V: Bircza, Krzywcza, Krukienice, Rybotycze), regulujące świadczenia rzędu zaledwie 100 gr, w tym osady wręcz karłowate, jak oppidulum Krakowiec, w ogóle do szosu niezobowiązany i czasem traktowany jako wieś.

Hierarchia miast ziemi sanockiej rysuje się inaczej (zob. wykres 3). Do kategorii miast większych, podobnie jak w ziemi przemyskiej, zalicza się tylko królewski Sanok (według szosu, czopowe klasyfikuje go w niżej, w III kategorii), brakuje tu natomiast licznej grupy ośrodków średnich, reprezentuje ją wyłącznie królewskie Krosno (niepewnie, tylko na podstawie jednej wpłaty) i biskupi Brzozów. Pozostałe, prywatne ośrodki to małe miasta (kategoria IV: Dubiecko, bliski wyższej kategorii Dynów, Rymanów) oraz miasteczka (kategoria V: Babice, Jaćmierz, Jawornik, Lesko, Nowotaniec i Zarszyn).

Jeszcze wyraźniejszą słabość objawiają miasta ziemi chełmskiej (zob. wykres 4). Nie ma na jej terytorium żadnego ośrodka z kategorii większych, w grupie średnich lokuje się zaś wyłącznie królewski Chełm (brak danych z Krasnegostawu). Wszystkie inne to małe miasta, zarówno królewskie, jak prywatne (kategoria IV: Szczebrzeszyn, Turobin i Wojsławice), a także najmniejsze miasteczka (kategoria V), wśród nich kilka stanowiących własność biskupia.

Nieco większe zróżnicowanie panuje wśród miast województwa bełskiego (zob. wykres 5). Mieści się tu jeden ośrodek dający się zaliczyć do większych (Busk), jeden do średnich (Bełz) oraz cztery do miast małych. Wszystkie należały do domeny królewskiej, a ponadto były w przeszłości centrami grodowymi. Miast prywatnych w żadnej z tych grup nie ma. Mają one rangę najmniejszych ośrodków (kategoria V). Niedorozwój dominialnej urbanizacji w Bełskiem, odziedziczony po okresie mazowieckiego władztwa, objawiał się więc nie tylko małą liczbą 
Wykres 2. Czopowe i szos z miast ziemi przemyskiej w latach 1507 i 1526 (w gr)

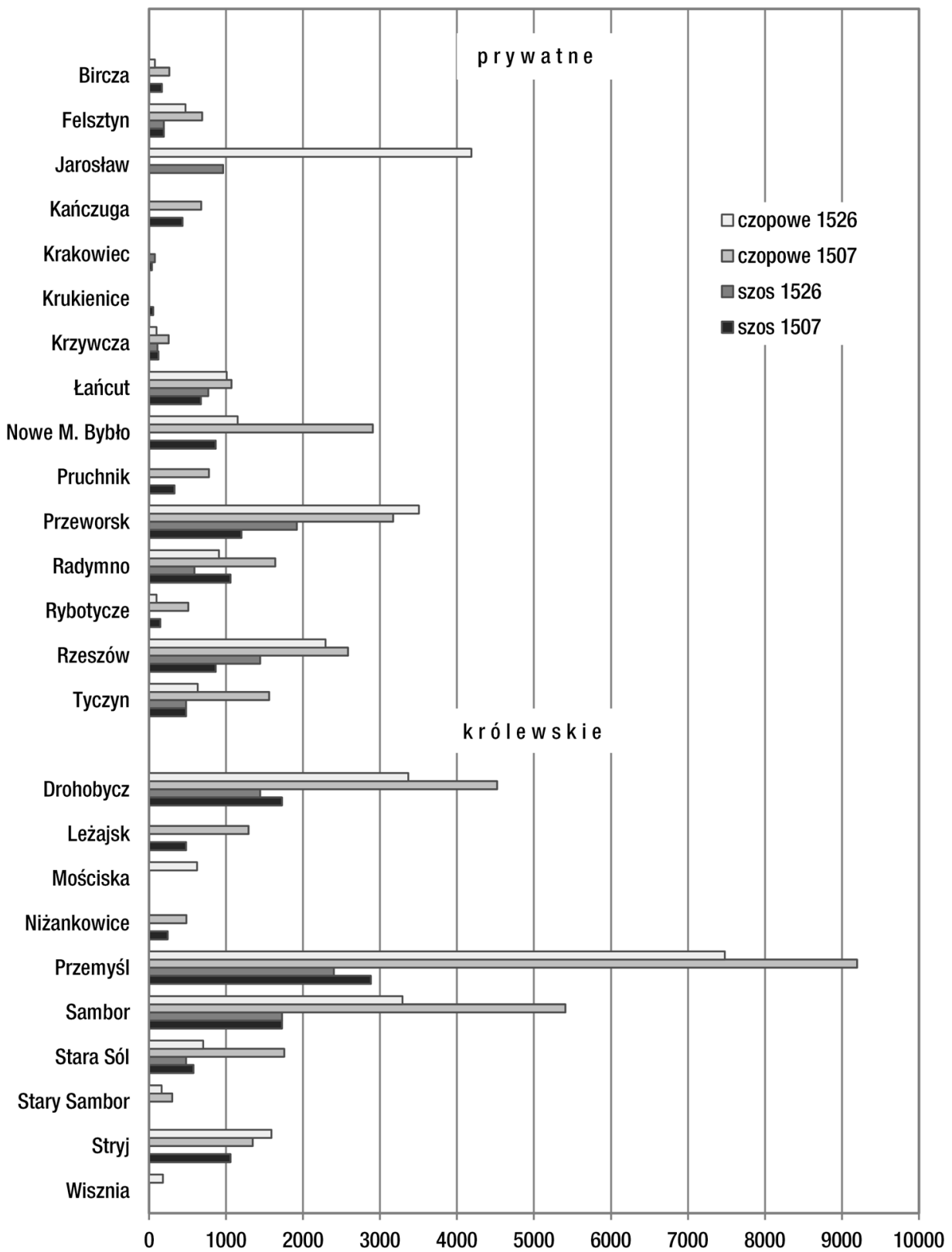

Źródło: AGAD, ASK, I 17, k. 1-8, 25-27v 20, k. 53-57v, 60-63. 
Wykres 3. Czopowe i szos z miast ziemi sanockiej w latach 1507 i 1526 (w gr)

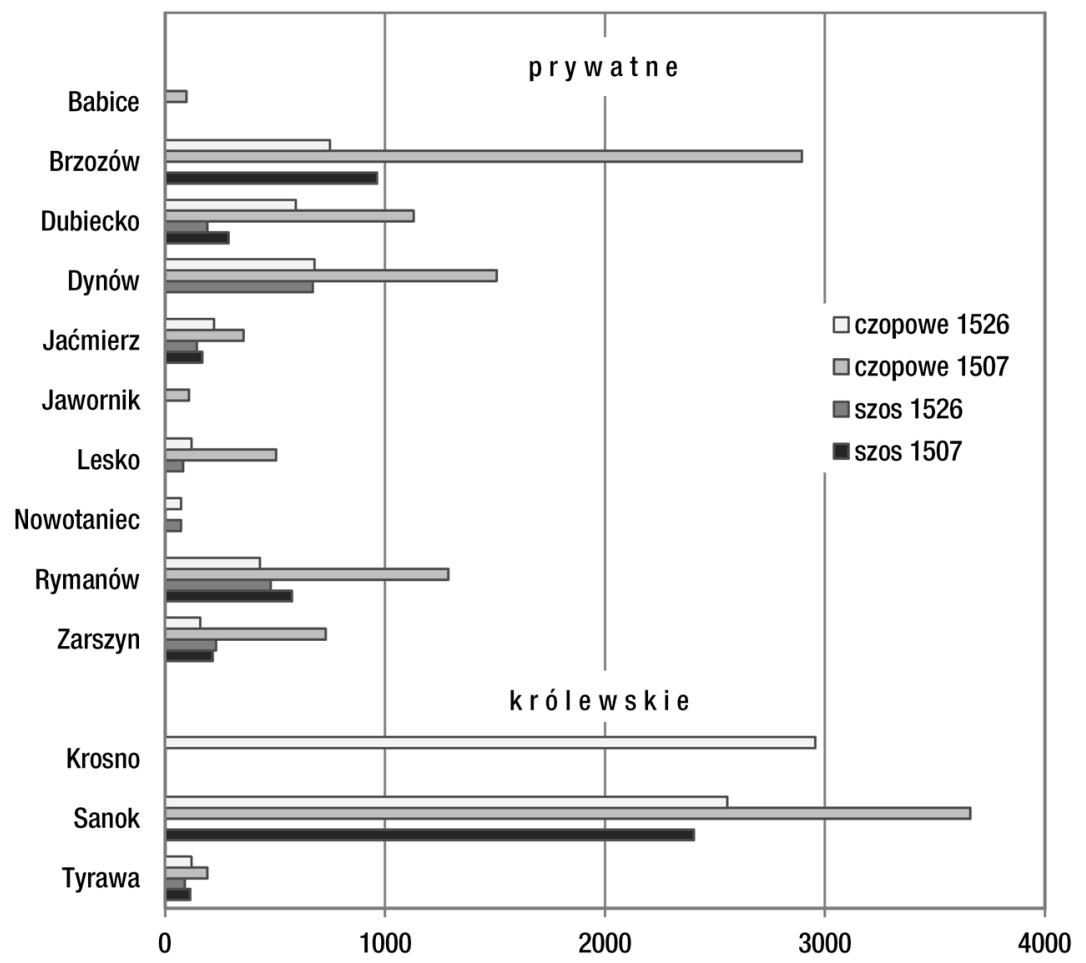

Źródło: AGAD, ASK, I 17, k. 9-13v, 28-29; 20, k. 58-59v , 64-65v.

ośrodków prywatnych (wyłącznie Rachanie i Uhnów, pozostałe dwa oznaczone na wykresie to miasta młode, lokowane na początku XVI w.), ale także ich słabością demograficzna, finansową i gospodarczą.

Zupełnie odmienny obraz przynosza dane podatkowe $\mathrm{z}$ miast ziemi lwowskiej (zob. wykres 6). Struktura zurbanizowania tej ziemi stoi pod znakiem przemożnej dominacji Lwowa. Lwów, jedna z trzech civitates maiores Królestwa według ustawy podatkowej z 1520 r., wpłacał przeciętnie 2,5 razy więcej czopowego oraz 4,5 razy więcej szosu niż kolejne miasto na Rusi, Przemyśl. W klasyfikacji przydziela mu to, jako jedynemu w dzielnicy, kategorię I. W obrębie ziemi lwowskiej jego supremacja jest jeszcze wyraźniejsza. Brak tu w ogóle reprezentantów kolejnej rangi miast większych (kategoria II), jako średnie zaś (kategoria III) daje się sklasyfikować wyłącznie królewski Gródek. Do miast małych (kategoria IV) zalicza się jedynie prywatne Olesko oraz królewskie Kamionka i Bóbrka. Wszystkie pozostałe, w liczbie 18, nie wykraczaja poza kategorię miasteczek. W jednakowym stopniu dotyczy to miast 
Wykres 4. Czopowe i szos z miast ziemi chełmskiej w latach 1510, 1531 i 1542 (w gr)

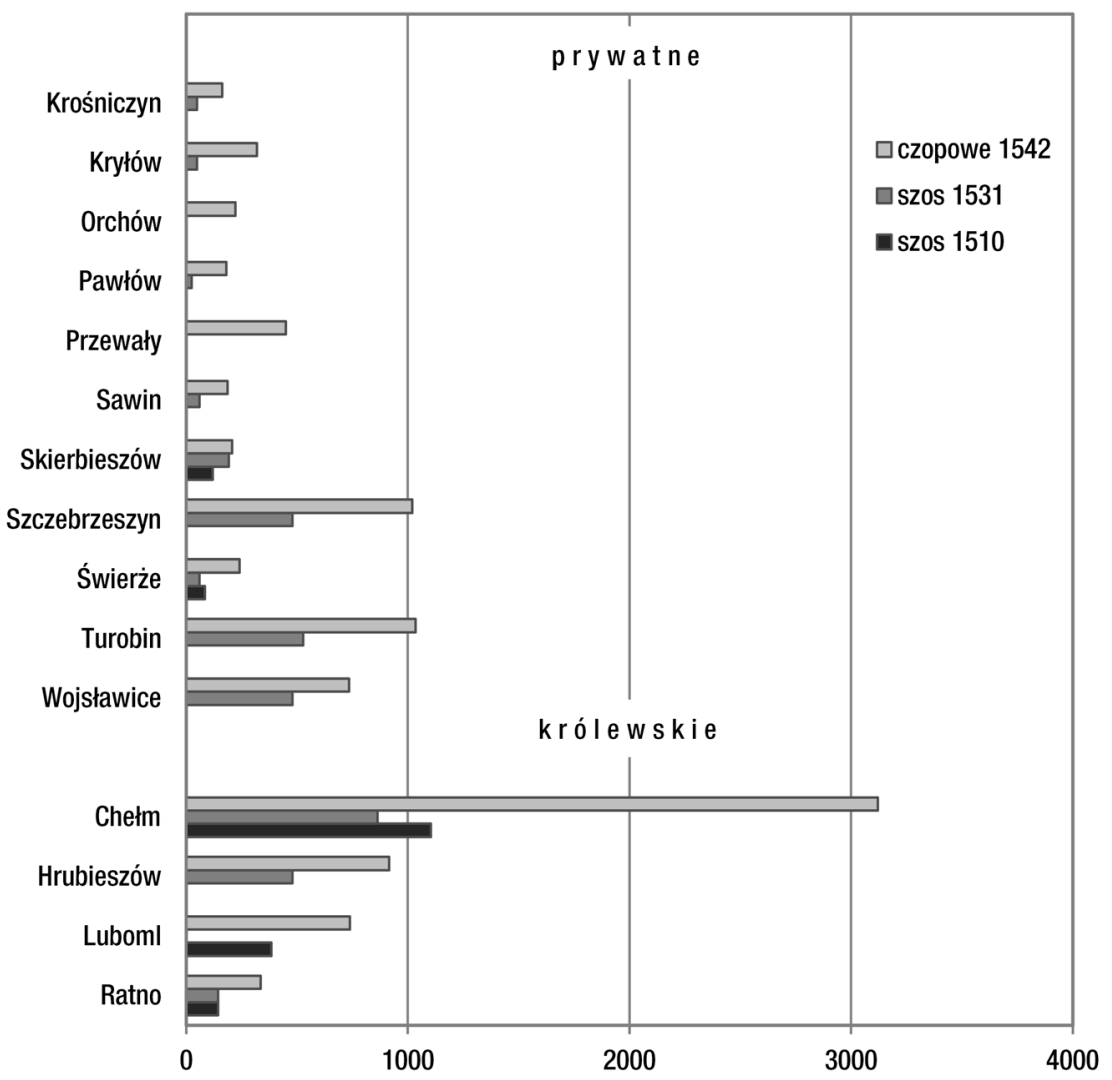

Źródło: AGAD, ASK, I 36, k. 167-170; 37, k. 250-252, 557-560v

królewskich, jak i prywatnych. Biegunowe skontrastowanie rangi stolicy i okolicznych ośrodków miejskich uwydatniają dysproporcje, wręcz przepaść między ich obciążeniami fiskalnymi: kilkaset zazwyczaj groszy wobec 12000 gr szosu i 20000 gr czopowego uiszczonego przez Lwów. Strefa tej przygniatajacej rozwój konkurentów dominacji Lwowa z pewnością rozciagała się poza ziemię lwowską, tu wszakże uwidoczniła się najmocniej.

Sklasyfikowanie miast ziemi halickiej (zob. wykres 7) można przeprowadzić jedynie połowicznie, ze względu na anonsowane, permanentne zwalnianie ich $\mathrm{z}$ powinności podatkowych. $\mathrm{Z}$ tych niepełnych informacji można wnioskować, że żaden $\mathrm{z}$ ośrodków nie osiagnął pozycji miasta większego, a za średnie (kategoria III) może jedynie uchodzić królewska Kołomyja (brak informacji o Trembowli). Nawet stolicę 
Wykres 5. Czopowe i szos z miast województwa bełskiego w latach 1507, 1531-1533 i 1542 (w gr)

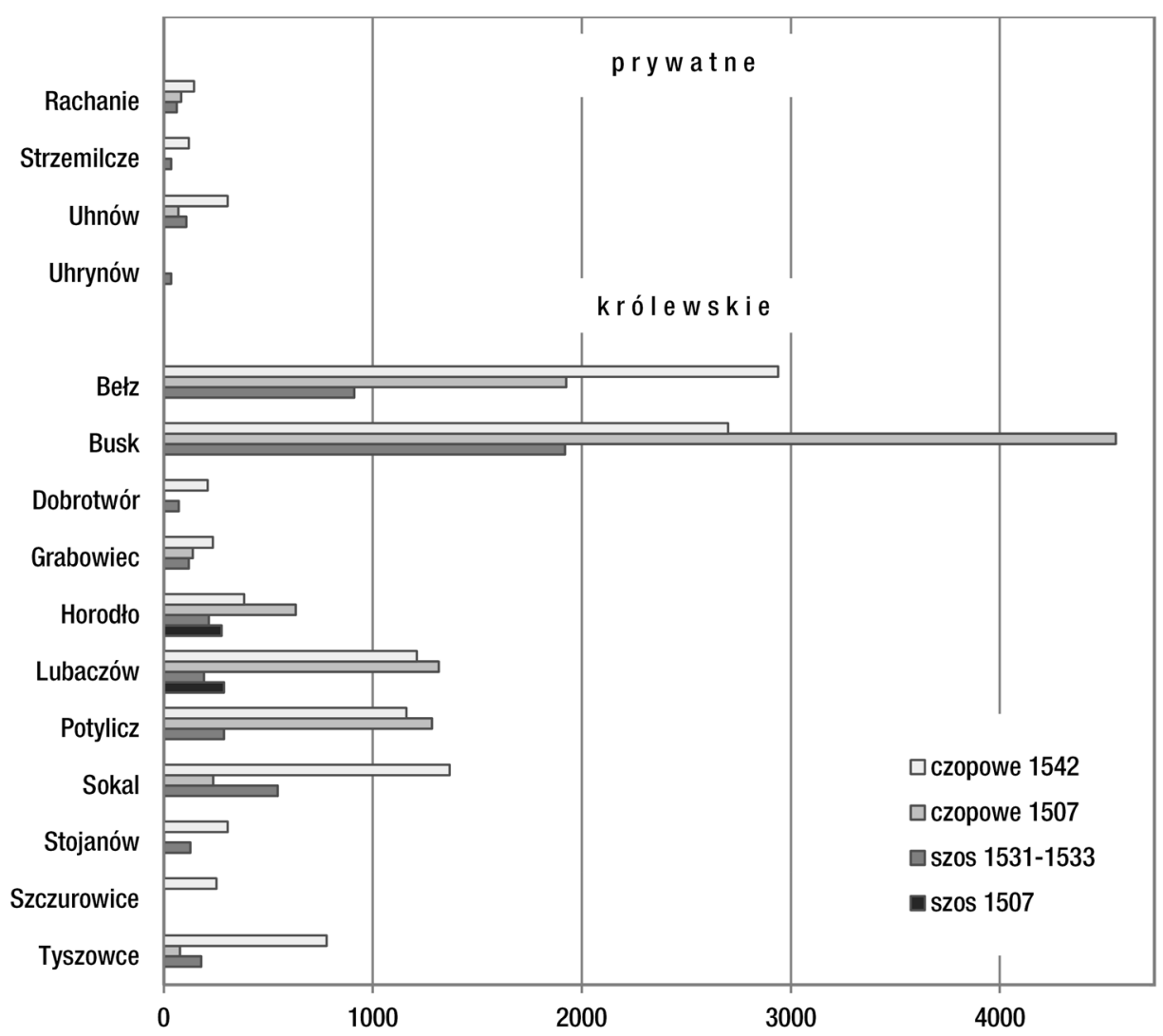

Źródło: AGAD, ASK, I 34, k. 638v-640; 36, k. 22-25, 37-39, 81-84v; 37, k. 553-556v.

ziemi, Halicz, który jest charakteryzowany tylko pojedynczą wpłata, a więc niepewnie, należy zaliczyć do miast małych (kategoria IV), podobnie jak - również królewski - Rohatyn. Wszystkie ośrodki prywatne mieszczą się w jeszcze niższej, ostatniej kategorii miasteczek.

Jak widać, w każdej z ziem Rusi uformowała się sieć miejska odznaczająca się swoimi własnymi cechami. Pomimo tego wyraźnego zindywidualizowania dostrzegalna jest jedna wspólna prawidłowość, obowiąująca w całej Rusi: miasta prywatne ustępują w swoich ziemiach randze miast królewskich ${ }^{40}$. Chociaż pośród tych ostatnich nierzadko

${ }^{40}$ Potwierdzaja to także wskaźniki pośrednie, jak obecność (poświadczona do 1530 r.) ludności żydowskiej, w 25 miastach królewskich i 10 szlacheckich, oraz fundacje klasztorne, przeprowadzone do 1500 r. w 15 miastach królewskich i jedynie 
Wykres 6. Czopowe i szos z miast ziemi lwowskiej w latach 1510 i 1526 (w gr)

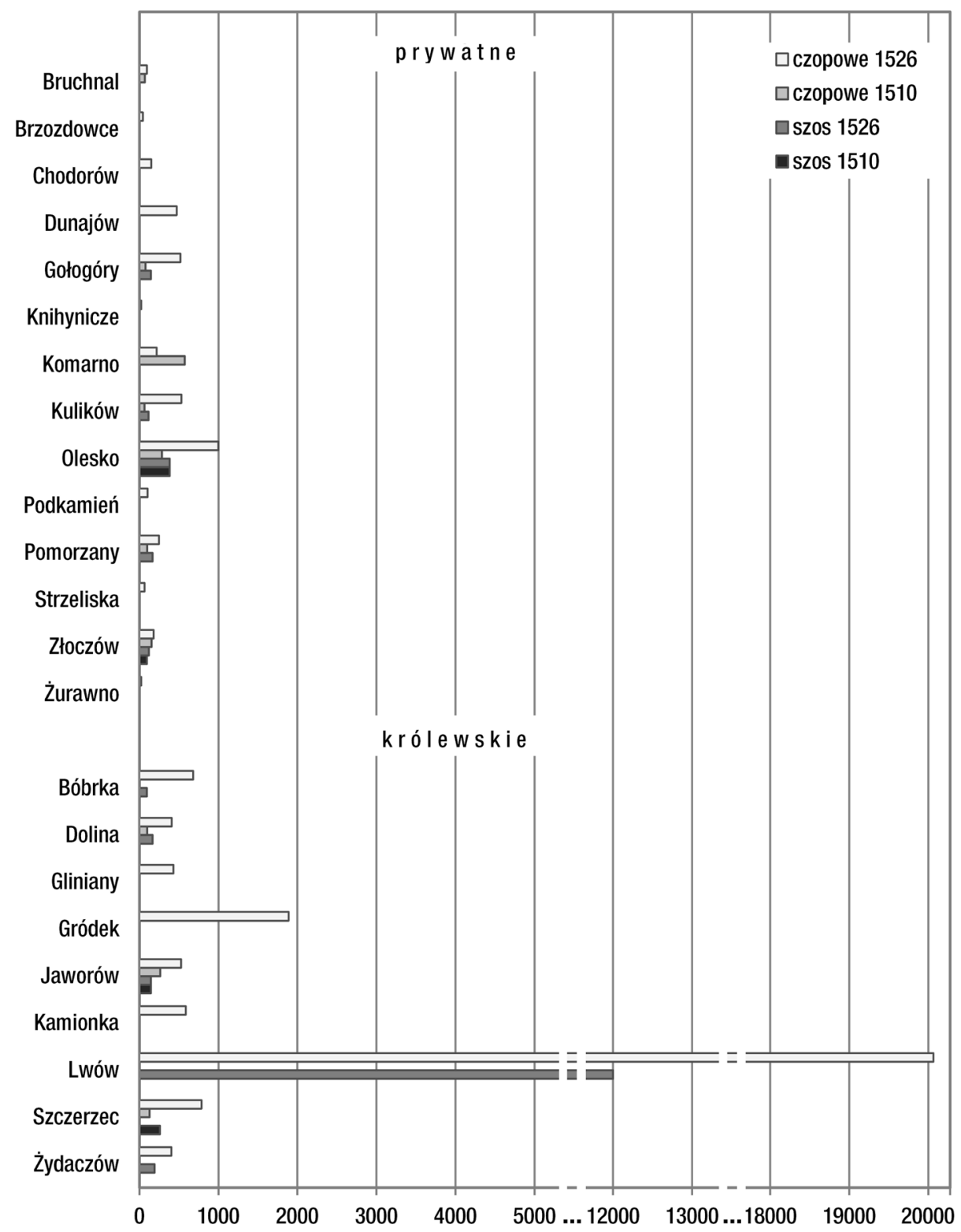

Źródło: AGAD, ASK, I 17, k. 15-20, 29v-31; 20, k. 188-188v , 201-202v. 
Wykres 7. Czopowe i szos z miast ziemi halickiej w latach 1515 i 1526-1530 (w gr)

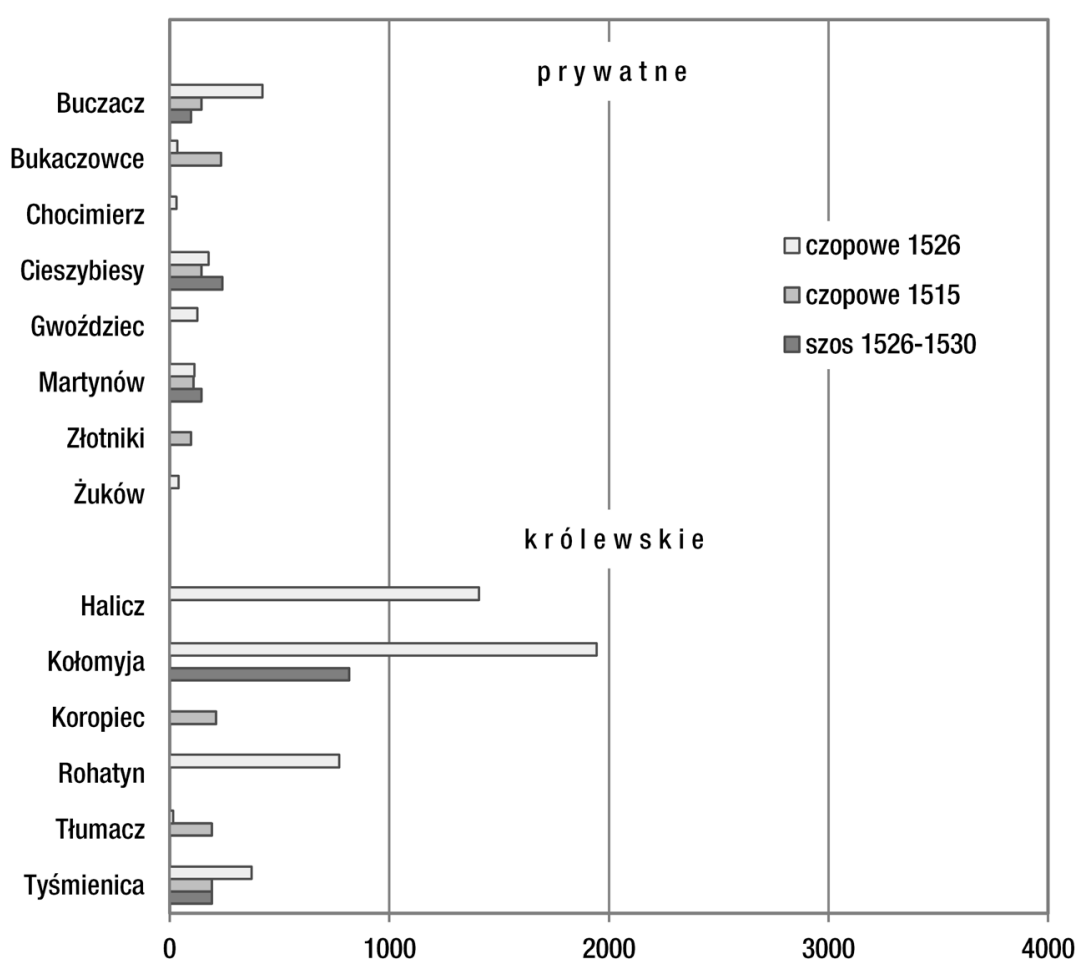

Źródło: AGAD, ASK, I 17, k. 21-24, 31-32; 20, k. 307-307v; 35, k. 140-141.

trafiają się ośrodki małe, to jest ich mniej niż wśród szlacheckich i duchownych. W swej miejscowej hierarchii, odnoszonej do ziemi, prym zawsze wioda miasta domeny. Żadne z miast prywatnych nie osiagnęło, w wymiarze danych fiskalnych, dobrze potwierdzonej kategorii ośrodka większego ${ }^{41}$. W gronie miast średnich (kategoria III) uplasowało się ich zaledwie siedem: Jarosław (według czopowego osiagał niski pułap II kategorii), Przeworsk (według szosu osiagał II kategorię), Łańcut

w 4 szlacheckich. Oba wskaźniki, pośród wielu innych, zostały użyte w rozwiniętej typologii miast Rzeszy, zob. M. Escher, F. G. Hirschmann, Die urbanen Zentren des hohen und späteren Mittelalters. Vergleichende Untersuchungen zu Städten und Städtelandschaften im Westen des Reiches und in Ostfrankreich, Bd. I, Thematischer Teil, Trierer Historische Forschungen 50/1, Trier 2005.

${ }^{41} \mathrm{O}$ generalizujacym zrównaniu miasto prywatne - małe miasto zob. ogólne obserwacje, które przedstawił P. Johanek, Landesherrliche Städte - kleine Städte. Umrisse eines europäischen Phänomens, w: Landesherrliche Städte in Südwestdeutschland, red. J. Treffeisen, K. Andermann, Oberrheinische Studien 12, Sigmaringen 1994, s. $9-25$. 
i Radymno (oba z ledwościa), Nowe Miasto Bybło, Rzeszów w ziemi przemyskiej oraz Brzozów w ziemi sanockiej; w pozostałych ziemiach żadne miasto tej rangi się nie uwidoczniło. Cztery z nich, poza biskupimi Radymnem i Brzozowem oraz Bybłem, miały za sobą długą tradycję ośrodków nadrzędnych.

Sprawowanie funkcji terytorialnych jeszcze w dobie państwa ruskiego i jego kontynuowanie po aneksji kraju działało jako silny czynnik miastotwórczy i warunkowało podejmowanie decyzji o przeprowadzeniu lokacji, bez względu na to, kto ją zamierzał: władca czy prywatny właściciel, obdarowany okręgiem i specjalnymi uprawnieniami. Utrwalone funkcje centralne tych ośrodków stanowiły też, jak się okazało, gwarancję ich pomyślnego - bardziej czy mniej - rozwoju w dobie polokacyjnej; część z nich osiagnęła rangę miasta większego (tylko królewskie) czy średniego, lecz nawet te, które należały do niższych kategorii, w hierarchii miejscowej zajmowały zwykle nieco lepszą pozycję. Poza wyróżniająca się grupa miast prywatnych ziemi przemyskiej można wskazać Szczebrzeszyn pośród miast prywatnych ziemi chełmskiej, któremu dorównywał jedynie Turobin, Olesko - relatywnie największe z miast prywatnych ziemi lwowskich, Buczacz - również stosunkowo największy wśród ośrodków prywatnych ziemi halickiej.

Ustalona grupa największych miast prywatnych, czyli średnich według przydzielonych kategorii podatkowych, wykazuje sporą zbieżność z lista miast secundi ordinis, wyliczonych z nazwy w ustawie o pogłównym z $1520 \mathrm{r}^{42}$ Figuruje na niej, spośród ośrodków prywatnych Rusi, jedynie pięć miast: Jarosław, Przeworsk, Łańcut, Rzeszów i Brzozów, a więc te same, które znalazły się w kategorii III. Różnica polega na naddatku jednego miasta (Bybło, jego pozycja jest zaskakująco wysoka) w klasyfikacji podług szosu i czopowego, i jednego w klasyfikacji według szosu (Radymno, podług czopowego jednak w kategorii IV). Klasyfikacji zawierających się pomiędzy dwiema niższymi rangami, małymi miastami i miasteczkami, w ten sposób zweryfikować nie można - ustawa z 1520 r. nie wymienia z nazwy żadnego ośrodka z dwóch najniższych ordynków.

Zbiorcze ujęcie przeprowadzonych klasyfikacji zostało zamieszczone na dwóch mapach (zob. mapy 5 i 6), jednej zawierającej uśrednione wartości czopowego, drugiej zaś szosu. Obie ukazuja podobny, wzajemnie wzmacniający się obraz, różniący się jedynie niekiedy szczegółami, a więc prymat dużych miast królewskich w każdej z ziem, ponadproporcjonalną liczebność ośrodków małych i najmniejszych, stanowiących

${ }^{42}$ Corpus iuris Polonici, t. 3, wyd. O. Balzer, Cracoviae 1906, nr 241. 
Mapa 5. Czopowe z miast Rusi Koronnej - średnia z wybranych lat 1507-1542 (w gr)

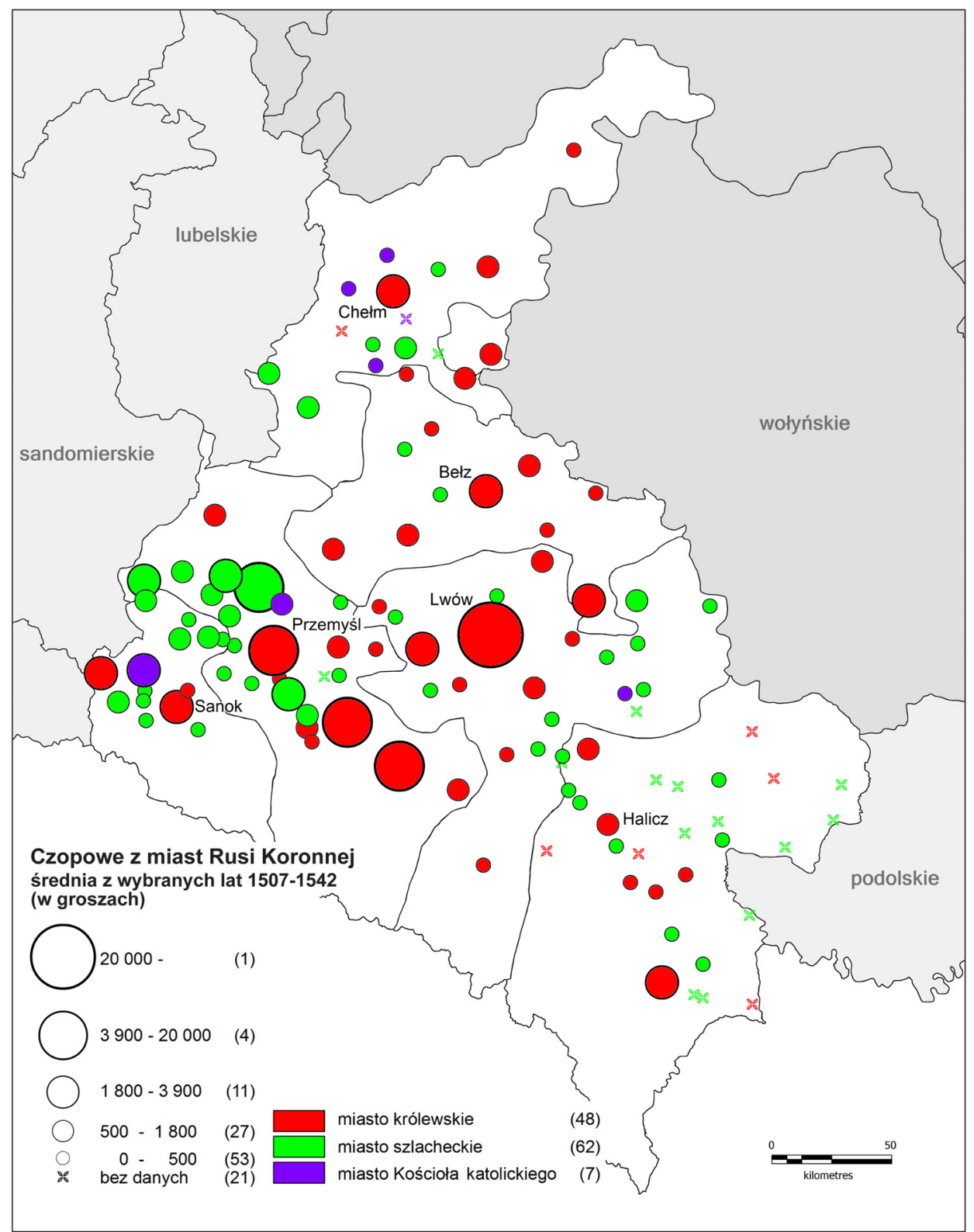

typ silnie dominujaccy zwłaszcza w grupie miast prywatnych, oraz skupienie się tych większych, nielicznych w tej kategorii własnościowej, w zachodniej połaci Rusi, przede wszystkim w ziemi przemyskiej, a ściślej w tzw. części zasańskiej, czyli na zachód do tej rzeki, wzdłuż głównej 
Mapa 6. Szos z miast Rusi Koronnej - średnia z wybranych lat 1507-1533 (w gr)

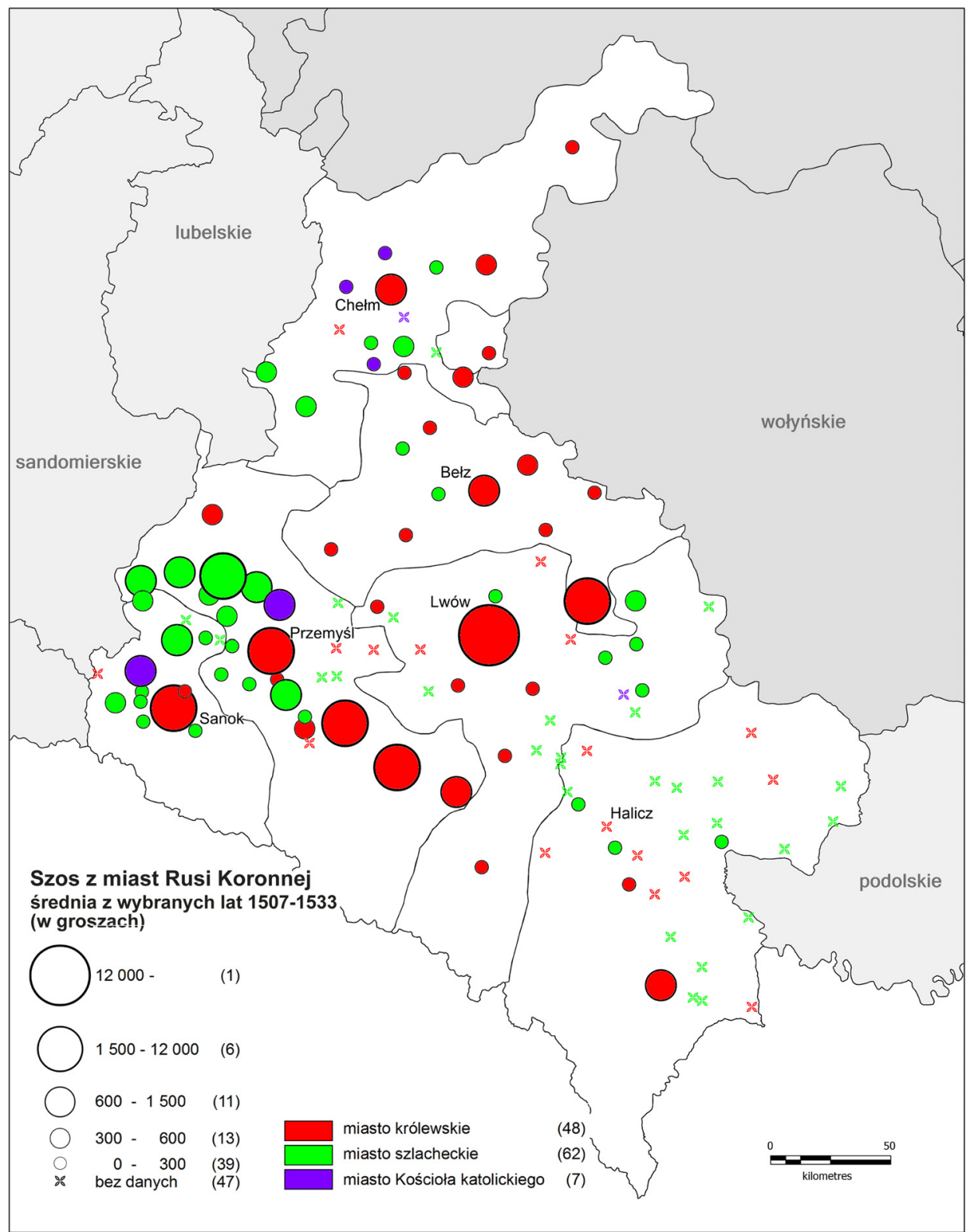

arterii regionu, krakowsko-lwowskiej osi drożnej. To zarazem, jak już wskazywano, region najwcześniejszych lokacji prywatnych.

Geneza urbanizacji dóbr prywatnych na Rusi, jej siły sprawcze i inicjatorzy, dominialny charakter, stosowane narzędzia i metody, a także 
cechy przebiegu, wreszcie rezultaty tej akcji w postaci sieci miast i miasteczek o typowych formach ustrojowych, organizacji społecznej i kształcie przestrzennym przypominaja żywo sytuację z rdzennych ziem Korony, a zwłaszcza z Małopolski. Można mówić o przeniesieniu, bez istotnych zmian, rozwiązań praktykowanych na ziemiach polskich i uznać urbanizację Rusi za kontynuację procesu miastotwórczego na nowym terytorium. Co najmniej dwie ważne okoliczności nadały jednak miastom ruskim odmienny charakter. Pierwsza to szczególne znaczenie funkcji obronnych, nawet nieujawniajacych się w postaci solidnych fortyfikacji, ale chociażby w zajęciu pozycji obronnej przez nowo lokowany ośrodek, w wykorzystaniu warunków terenowych lub ich umiejętnym dostosowaniu. Druga cecha to złożony układ etniczny i wyznaniowy. Ponieważ obie te właściwości w równej mierze dotyczą tak miast królewskich, jak i prywatnych, właściwsze do ich rozpatrywania jest inne, wspólne ujęcie.

\section{$* * *$}

Przeprowadzona analiza ruchu zakładania miast prywatnych na Rusi na tle procesów urbanizacji dzielnicy oraz próba sklasyfikowania ich rangi w całej sieci miejskiej przynosi tylko częściowy obraz sytuacji. Dla określenia miejsca, jakie zajmowały ośrodki prywatne $\mathrm{w}$ miejskich strukturach kraju, powinien on być uzupełniony o rozpatrzenie ich funkcji, kształtu społecznego i form życia miejskiego, co jest znacznie trudniejsze, mniej uchwytne w materiale źródłowym i tylko z rzadka, dla kilku zaledwie miast, może być rozpatrywane; szczególnie źle przedstawia się to $\mathrm{w}$ przypadku miast prywatnych przed XVI stuleciem. Funkcjonowanie i zadania gospodarcze miasta późnośredniowiecznej Rusi Koronnej, a zwłaszcza małego miasta i miasteczka, najpowszechniejszego efektu urbanizacji czy może właściwiej semiurbanizacji, to temat potrzebnych studiów szczegółowych. Wielostronne badania roli miasta $\mathrm{w}$ planie gospodarstwa dominialnego, do którego ono należało, uwzględniające przy tym różne potrzeby, nie tylko ekonomiczne, ale też badania prowadzone w planie rynków lokalnych i regionalnych, w których funkcjonowaniu brało ono udział, pozwoliłyby lepiej zrozumieć fenomen żywiołowej urbanizacji i jej charakterystycznej, zwykle rachitycznej postaci. W jego tłumaczeniu i wskazywaniu na dominialna genezę odwołujemy się do dorobku historiografii, która swe obserwacje wywodziła z macierzystych ziem Korony. Jest to bez wątpienia zasadne ze względu na wspólnotę tego samego zjawiska, przesuniętego w czasie i przestrzeni, ale pomija miejscową specyfikę, własne rysy 
i lokalne uwarunkowania. Niektóre z nich, jak formowanie władztw terytorialnych i uzależnienie najwcześniejszej sieci od starego systemu grodowego, zostały tu zauważone, inne, jak potrzeba skonsolidowania dopiero formujących się włości, której miejska inwestycja dobrze odpowiadałaby, oraz obronny walor osiedli miejskich, na Wschodzie szczególnie pożądany, zostały tylko zasygnalizowane, nie są one zapewne jedyne i zagadnienie wyczerpujace.

\section{Bibliografia}

Bogucka M., Samsonowicz H., Dzieje miast i mieszczaństwa w Polsce przedrozbiorowej, Wrocław 1986.

Fastnacht A., Osadnictwo ziemi sanockiej w latach 1340-1650, Wrocław 1962. Horn M., Miejski ruch osadniczy na Rusi Czerwonej do końca XV wieku, RDSG, t. 35, 1974, s. 49-74.

Janeczek A., Faktorie, powiaty $i$ dwory. Trzy sfery miejskiego ruchu lokacyjnego na Rusi Czerwonej (XIII-XV wiek), w: Procesy lokacyjne miast $w$ Europie Środkowo-Wschodniej, red. C. Buśko, M. Goliński, B. Krukiewicz, Wrocław 2006 (Acta Universitatis Wratislaviensis, 2985), s. 421-445. Janeczek A., Osadnictwo pogranicza polsko-ruskiego. Województwo betskie od schytku XIV do poczqtku XVII w., Wrocław 1991.

Szczygieł R., Lokacje miast w Polsce XVI wieku, Lublin 1989.

Wiesiołowski J., Sieć miejska $w$ Wielkopolsce $w$ XIII-XVI wieku. Przestrzeń $i$ społeczeństwo, KHKM, t. 29, 1980, nr 3, s. 385-299.

Andrzej Janeczek

Private towns in Crown Ruthenia until the end of the $15^{\text {th }}$ century (Summary)

In the aftermath of the political changes taking place in Central and Eastern Europe in mid-14 ${ }^{\text {th }}$ century, the Kingdom of Poland gained territory in form of the fallen Halič-Volhynian Duchy. The new province of the Kingdom, Red Ruthenia, had earlier formed part of the Byzantine-Ruthenian cultural sphere. The annexation of Ruthenia entailed numerous systemic, social, economic, and cultural transformations aimed at the integration and modernisation of the Crown's new acquisition. One of these transformations was the process of urbanisation, implemented in line with the model applied in the Polish territory, based on the so-called German law (iure Theuthonico).

The process of urbanisation of Red Ruthenia began soon after the political breakthrough. In the initial period of this tumultous development, that is in mid- $14^{\text {th }}$ century, only four centres of the former Halič-Volhynian Duchy had 
contact with the occidental type of urban organisation (urban communes in Przemyśl and Lviv, following the German law in the first half of the $14^{\text {th }}$ century, self-government commune in Włodzimierz of the same period, Sanok town chartered in 1339). At least 32 towns existed in the Ruthenian region of the Crown in ca. 1400, while in 1500, ca. 117 towns existed in the area (fig. 4). Out of these, 48 were owned by the king, 69 by the nobility and the Catholic Church. Private town foundations, initially not as widespread, outnumbered the amount of royal initiatives as soon as in the second half of the $15^{\text {th }}$ century (chart 1). Private towns belonged primarily to magnates and wealthy nobility; only seven ecclesiastical towns were founded in the area, which is an indication of the poor financial situation of the Catholic Church in Ruthenia.

Two types of towns can be distinguished in the process of private town foundation in Ruthenia. The older type are towns founded in the centres of former castellanies, which were granted to magnate families in their entirety and with special privileges. The old castellany, still serving as the local centre, was converted into a town under German law. The other type, which appeared later than the first one, were towns founded in the process of construction of new noble estates and ecclesiastical property. It served to urbanise ordinary rural settlements or develop empty sites through creating towns - centres of the forming private estates. Towns of both types were organised according to the same set of rules. A characteristic feature of the urban landscape of Ruthenia forming in Late Middle Ages was systemic uniformity, but at the same time individual centres varied in size, importance, and function.

In order to analyse the variety of towns, a classification of urban centres is applied. It is based on fiscal sources from the first half of the $16^{\text {th }}$ century: municipal wealth tax (Polish: szos, from German: Geschoss) and excise tax on production and consumption of alcoholic beverages, primarily beer (Polish: czopowe, from Polish: czop 'bung', Latin: ducillaria). According to this classification, encompassing not only the evaluation of the town's population, but also its wealth, scale of consumption and economic power, the vast majority of private towns were small settlements or dwarf towns (category IV and V). Only seven private towns can be classified as middle-sized (category III). They were all located in the western region of Red Ruthenia (fig. 5, 6), intensely colonised as early as in the second half of the $14^{\text {th }}$ century. Category I (only Lwów/Lviv/ Lemberg) and II (six towns) were composed exclusively of royal towns. The dominance of small towns was characteristic of the entire urban landscape of Red Ruthenia, but it was most visible among private towns.

Andrzej Janeczek - dr hab., profesor Instytutu Archeologii i Etnologii PAN w Warszawie, kierownik Zakładu Historii Kultury Materialnej Średniowiecza i Czasów Nowożytnych, mediewista. Zajmuje się historią ziem wschodnich Korony. E-mail: janeczek@iaepan.edu.pl. 